\title{
Ulusal Yazın Bağlamında İșten Ayrılma Niyetinin Öncüllerine İlişkin Bir Meta-Analiz Çalışması
}

\author{
Deniz DİRIK*
}

\begin{abstract}
$\ddot{O} Z$
Bu çalıșma, ulusal/uluslararası nitelikli hakemli dergilerde yayımlanan ve Türk örneklemlerinden toplanan ampirik veriye dayalı makaleler üzerinden, işten ayrlma niyetinin ilişkili olduğu öncü değişkenleri meta-analitik yöntemle incelemeyi ve işten ayrllma niyetinin öncüllerinin detayl bir modelini ortaya koymayl hedeflemektedir. Çalışma kapsamında gerçekleștirilen, korelasyon değerlerine dayanan on beș adet meta-analize göre ișten ayrılma niyetinin en slk ilişkilendirildiği değişken iş tatmini olup, orta-yüksek düzeylerde negatif yönlü ilişki söz konusudur $(E B=-0,478, p<0,00)$. Örgütsel bağlllık boyutlarl üzerinden yapılan analize göre, işten ayrllma niyeti ile en yüksek ilişsi duygusal bağlllık $(E B=-0,462, p<0,00)$ ve en düşük ilişki devam bağlllığl $(E B=-0,082, p<0,00)$ alt boyutlarında görülmüş̧tür. Özdeşleşme ve işten ayrılma niyeti arasındaki negatif yönlü ilişki zaylf düzeydedir $(E B=-0,278, p<0,00)$. Işs stresi ise işten ayrılma niyeti ile orta düzeylerde ve pozitif yönlü ilişkilenmiştir $(E B=0,395, p<0,00)$. Iş̧ performansı ve işten ayrlma niyeti arasındaki negatif yönlü ilişkinin ise beklentinin aksine son derece zaylf ve ihmal edilebilir düzeyde olduğu görülmüştür $(E B=-0,133, p<0,00)$. Çalışmanın, ulusal yazına konu olan ampirik araştırmalar üzerinden, işten ayrlma niyetinin kapsamlı ve güncel bir panoramasinı sunması açısından yazına katkıda bulunacă̆ı düşünülmektedir.
\end{abstract}

Anahtar Kelimeler: İşten ayrllma niyeti, meta-analiz, işten ayrllma niyetinin öncülleri, ulusal yazında işten ayrllma niyeti

JEL Sinıflandirmast: $M 0, M 1$, M5

\section{A Meta-Analytic Review of Studies on the Antecedents of Intention to Leave in Turkish National Literature}

\begin{abstract}
This study aims to make a systematic review of studies on the antecedents of "intention to leave" in the context of articles featuring samples from Turkey and published in national/international peer-reviewed journals, and hence to generate a comprehensive model of intention to leave antecedents. According to fifteen different meta-analyses based on correlation coefficients, the most frequently investigated antecedent of intention to leave is job satisfaction, and there is a medium to high level negative correlation (ES=-0,478, $p<0,00)$. Organizational commitment meta-analyses reveal that the highest correlation occurs with affective commitment $(E S=-0,462, p<0,00)$ and the smallest correlation occurs with continuance commitment (ES=$0,082, p<0,00)$. The negative correlation between identification and intention to leave is quite small $(E S=-0,278, p<0,00)$. Job stress and intention to leave are positively correlated at a medium-level $(E S=0,395, p<0,00)$. However, there is a very small and negligible correlation between intention to leave and job performance, contrary to prevailing opinion $(E S=-0,133, p<0,00)$. We expect this paper to make a modest contribution to the extant literature on the intention to leave by providing a comprehensive and up-to-date review of the empirical studies in the national context.
\end{abstract}

Key Words: Intention to leave, meta-analysis, antecedents of intention to leave, intention to leave in national literature

JEL Classification: $M 0, M 1, M 5$

\footnotetext{
* Arş. Gör. Dr., Manisa Celal Bayar Üniversitesi, İ̈BF, İşletme Bölümü, deniz.ispirli@cbu.edu.tr (Makale Gönderim Tarihi: 01.02.2019/ Yayına Kabul Tarihi: 17.03.2019)
} 


\section{GİRIŞ}

İșten ayrılma niyeti, çalışanların iş çevresindeki koşullara ilişkin memnuniyetsizliği sonucunda ortaya çıkan işten ayrılmaya yönelik bir karar, niyet ve işten ayrılma tutumunun bir adım öncesi olarak tanımlanmaktadır (Serçeoğlu vd., 2016). İşten ayrılma niyetinin belirdiği andan itibaren, çeşitli koşullar işgöreni işten ayrılmamaya itse dahi, verimlilik kaybının, performansta düşüşün ve tatminsizliğin önlemez olacağ 1 değerlendirilmektedir. $\mathrm{Bu}$ anlamda işten ayrılma niyeti, örgüt tarafından bilinçli bir biçimde dayatılmadığı varsayımı altında, örgüte ciddi maliyetler ve negatif dişsallıklar yükleyen, örgütsel alanda istenmeyen ve tedbir gerektiren bir örüntü olarak karşımıza çıkmaktadır. Örgütlerin ve yöneticilerin işten ayrılma niyetini ve bu niyetin tetikleyeceği sonuçları engelleyebilmesi ise, bu tutuma etki eden faktörleri tanımlamayı ve bu tutumun etkilediği değişkenlerin kümesini/ilişkilerin boyutunu tespit etmeyi gerekli kılmaktadır. Kuramsal ve ampirik araştırmalar, işten ayrılma niyetini çeşitli öncüller ve sonuç değişkenleri ile bir arada irdelemektedir. İşten ayrılma niyetini etkileyen faktörler genel olarak kişi/iş/örgüt çevresi olmak üzere üç bağlamda ele alınmaktadır (Cotton ve Tuttle, 1986). Bazı araştırmalarda ise işten ayrılma niyetini etkileyen faktörlerin ekonomik (ücret, harici olasıllklar, eğitim/yetiştirme, şirket büyüklüğü gibi), demografik (yaş, kıdem gibi) ve psikolojik faktörler (psikolojik sözleşme, iş tatmini, örgütsel bağl1lık, iş güvencesizliği gibi) şeklinde kategorize edildiği görülmektedir (Perez, 2008). İşten ayrılma niyetinden etkilenen sonuç değişkenleri ise başta işten ayrılma davranışı olmak üzere bazen döngüsel bir yapı arz etmekte ve işten ayrılma niyetine etki eden faktörlerin, işten ayrilma niyetinden etkilenen faktörlere de dönüşebildiği görülmektedir. Nihayetinde, işten ayrılma niyetinin performans kaybı, verimlilikte düşüş ve tatmin gibi duyuşsal değişkenlerde azalmaya yol açtığı araştırmalarla ortaya konmaktadır (Gündüz- Çekmecelioğlu, 2005; Gül vd., 2008).

İşten ayrılma davranışının en kritik öncülü olması açısından, işten ayrılma niyeti, kültürel, örgütsel, sektörel ve birey bazında incelenmesi gereken bir değişkendir. İşten ayrılma konusuna odaklanan bireysel çalışmalar, bu niyetin yordayıcılarına ve kısmen sonuçlarına ilişkin olarak farklı bağlamlardan ve zamanlardan kanıt üretmektedir. Ülkemizde, işten ayrılma niyeti konusunda farklı disiplinlere mensup araştırmacılarca yapılan çalışmalar ise işten ayrılma niyetinin özellikle öncülleri bağlamında kapsamlı bir modelini ortaya koymaya yetecek nitelik ve niceliğe ulaşmış görünmektedir. Bu anlamda, bu çalışmada, ulusal yazın kapsamında işten ayrılma niyeti konusunda yapılan ampirik araştırmalar üzerinden sistematik bir inceleme yapılması hedeflenmektedir. Spesifik olarak bu çalışma, ulusal/uluslararası nitelikli hakemli dergilerde yayımlanan ve Türk örneklemlerinden toplanan ampirik veriye dayalı makaleler üzerinden, işten ayrılma niyetinin ilişkili olduğu öncü değişkenleri meta-analitik yöntemle incelemeyi ve işten ayrılma niyetinin öncüllerinin detaylı bir modelini ortaya koymayı hedeflemektedir. 


\section{KAVRAMSAL ÇERÇEVE}

İşten ayrılma niyetini inceleyen araştırmaların dayandığ 1 kuramların incelendiği çalışmalarda (Ngo-Henha, 2017; Perez, 2008), işten ayrılma niyeti konusunda yapılan çalışmalarda beklenti kuramı, beşeri sermaye kuramı, eşitlik kuramı, kaynak temelli yaklaşım, Herzberg'in çift faktör kuramı, işe gömülmüşlük kuramı, sosyal mübadele kuramı ve örgütsel denge kuramına sıklıkla atıfta bulunulduğu tespit edilmiştir. Bu kuramlar, işten ayrılma niyetinin nasıl ortaya çıktığını ve hangi faktörlerden etkilendiğini ortaya koymaya çalışmaktadır. Yine bu araştırmalar, işten ayrılma niyetinin "gönüllü” olarak ortaya çıktığı varsayımı altında hareket etmektedir. Nitekim, işten ayrılma davranışının çeşitli gerekçelerle öznenin gönüllü kararı olmaması veya örgüt tarafindan dayatılması, örgütçe istenmeyen sonuçlar üretmeyecek ve mücadele edilmesi gereken zararlı bir örgütsel davranış örüntüsü olarak yorumlanmayacaktır. Ancak, işten ayrılma niyeti konusunda kurgulanan araştırma modelleri, ekseriyetle bunu istenmeyen bir tutum olarak irdelemekte, işten ayrılma niyetiyle nasıl başa çıkılabileceğini keşfetmeye çabalamakta ve örgütün zarar göreceğine ilişkin gizli bir nedensellik varsaymaktadır. Çalışanların gönüllü olarak işten ayrılma kararı ise, yetenekli işgörenlerin kaybı dolayısıyla sosyal sermayenin azalması, geride kalanların morallerinde düşüş, kaybedilen sosyal sermayeyi ikame etme maliyetleri, eğitim/yetiştirme maliyetleri, çalışan bağlılığında azalma, ekip çalışmasının sekteye uğraması ve ekip dinamiğinin bozulması, projelerin yarım kalması/sonlanması ve örgütün itibarının aşınması gibi sonuçlarla ilişkilendirilmektedir (Bodla ve Hameed, 2008; Perez, 2008; Winterton, 2004). Bu anlamda, çok sayıda akademik araştırmaya konu olan "işten ayrılma niyeti" olgusu, aktörce arzulanan, istemli ve örgüt açısından olumsuz sonuçlar üreteceği varsayılan bir desen olarak incelenmektedir.

Bu ön kabul altında, Barnard ve Simon (Burrell ve Morgan, 1979: 148) ile March ve Simon (1958) tarafından geliştirilen örgütsel denge kuramına (organizational equilibrium theory) dayanan yaklaşımlara göre, çalışanların işyerinden beklentileri ile işyerinin çalışanlardan beklentileri arasındaki denge işten ayrılma niyetinin temel belirleyicisidir. $\mathrm{Bu}$ bağlamda, işten ayrılmanın arzulanma derecesi ile kolaylığı, bir çalışanın algıladığı dengenin ve iş tatmininin öncülüdür. Denge kuramı, iş tatmini, örgüt büyüklüğ̈̈, başka bir işe transfer olma olasıllı̆̆ ve bunun arzulanma düzeyi arasında döngüsel bir ilişki öngörür. İşgören devri örgütün büyüklügünü etkilerken, örgütün büyüklüğü transfer olma olasılığını ve bu olasılık ise işten vazgeçme arzusu dolayısıyla işgören devrini etkileyerek döngüyü yeniden başlatır (March ve Simon, 1958'den akt. NgoHenha, 2017). Homans'in (1958) sosyoloji kökenli sosyal mübadele kuramına göre, sosyal aktörler arasındaki ilişki, tarafların toplumsal kurallara ve üzerinde uzlaşılan mübadele normlarına uyma düzeyleri ile paraleldir. İlişkilere yapılan maddi ve manevi yatırımlar ilişkinin niteliğine göre güven, sadakat, bağlilık gibi sonuçlar üretirken, karşıl1kl1l1k, belirleyici bir rol üstlenir. İşten ayrılma niyeti özelinde ele alındığında sosyal mübadele, yönetim veya iş arkadaşları tarafından bariz veya örtük normların ihlal edilmesi sonucunda bireyin gönüllü olarak ve 
sözlerin tutulmaması nedeniyle işi bırakmaya sevk olması anlamına gelir. Benzer biçimde eşitlik kuramı, çalışanların hakkaniyet algıları bağlamında işe motive olduklarını ve katkıları ölçüsünde beklentilere girdiklerini ileri sürerek, hakkaniyetsizliği düzeltme umudu kalmayan çalışanların işten ayrılma niyetlerinin artacağ 1 şeklinde ilgili yazına uyarlanmıştır (Berry ve Morris, 2008). İşe gömülmüşlük kuramı, çalışanların hem sosyal çevrelerinde hem de örgütsel yaşamlarında çok sayıda bağlantı kurdukları, bu anlamda işlerine ve çevrelerine yoğun biçimde gömülü oldukları (özellikle iş arkadaşları, akrabalar ve arkadaşlar) ve zamanla bu bağlantılardan vazgeçemez noktaya vardıkları savından beslenmektedir (Zhang vd., 2012). Çalışanların işe gömülmüşlük düzeyleri ise kişisel değerler, kariyer hedefleri, bilgi ve beceriler, örgüt kültürü, iklim, işin gerekleri gibi çok sayıda faktörden etkilenmektedir. İşten ayrılma niyeti özelinde, çalışanların mesleki ve sosyal anlamda kendilerini ne derece işe gömülmüş hissettikleri belirleyici olmakta ve işe gömülmüşlüğü düşük çalışanlar, alternatifleri değerlendirebilmektedir. Herzberg'in çift faktör kuramı, hijyen faktörleri ve motivatörler arasındaki ayrımı (ancak karşıtlığı değil) esas almakta ve tanınma, başarma, işin ilgi çekiciliği gibi motivatörlerin iş tatmini noktasındaki önemine vurgu yapmaktadır. İlaveten, hijyen faktörleri olarak tanımlanan çalışma koşullarının uygunluğu, adil ücretlendirme, şirket politikaları, iş güvenliği gibi unsurlar da çalı̧̧an tatminini belirleyici rol oynamaktadır (Herzberg, 1966). Buna göre, bir çalışanın işinden memnun olması ve dolayısıyla işten ayrılma niyeti beslememesi hem hijyen faktörlerinin hem de motivatörlerin dengeli bir fonksiyonu olmaktadır. Beşeri sermaye kuramı ile kaynak temelli yaklaşımdan yola çıkan çalışmalar ise, çalışanların kendilerini değerli, rekabet avantajı sağlayan, şirkete katkıları yadsınamaz ve önemli entelektüel kaynaklar olarak algıladıkları ölçüde ve şirketlerinin, kendilerine eğitim, yetiştirme, kariyer yönetimi gibi alanlarda yatırım yaptıkları sürece işten ayrılma niyetinden uzaklaşacaklarını savunmaktadır (Armstrong ve Shimizu, 2007; Zula ve Chermack, 2007). İlgili kuramlar ve yaklaşımlar, gönüllü ve örgütçe istenmeyen (sağlıksız) türden işten ayrılma niyetinin nasıl geliştiğine ve hangi politikalarla engellenebileceğine açıklık getirmeye çalışan, birbirini (ikame edici olmaktan ziyade) tamamlayıcı nitelikte kavramsal çerçeveler olarak değerlendirilebilir. İşten ayrılma niyeti ile ilgili çalışmalar, her ne kadar bu kuramsal yaklaşımları tartışmasalar da örtük biçimde bu yaklaşımların varsayımlarından beslenmekte ve araştırma modellerinin bu kuramsal dayanaklardan esinlendiği görülmektedir. Ayrıca çalışmalarda, kuramsal yaklaşım ve model karmaşası da yaşanmaktadır ve bu ikisi arasındaki ayrımın gözetilmediği dikkat çekmektedir. Yukarıdaki kuramsal yaklaşımlardan farklı olarak, örneğin Mobley'in (1977) işgücü devri kararını bir süreç olarak inceleyen modeline göre, işten ayrılma davranışı bilişsel birtakım süreçler silsilesinden oluşur. Birey sırasıyla, mevcut istihdam koşullarını değerlendirir; işten tatmin olup olmama durumunu yoklar; alternatif iş arayışı düşüncesinin fayda ve maliyetlerini hesaplar; iş arama niyeti belirir; mevcut iş ve alternatif işler kıyaslanır; işten ayrılma niyeti doğar ve nihayetinde işten ayrılma davranışı sergilenir. Benzer şekilde, Allen ve arkadaşlarının (2003) modeline göre 
işten ayrılma niyeti (ve akabinde gelişen işten ayrılma davranışı) algılanan örgütsel destek, iş tatmini ve örgütsel bağlılığın bir fonksiyonudur ve bu değişkenlerle olumsuz biçimde ilişkilenmektedir. İşten ayrılma konusunun kapsamlı olarak incelendiği bir çalışmada (Holtom vd., 2008) kuramsal ve ampirik modeller tarihsel olarak sınıflandırılmış ve 1985 öncesi yazının genellikle birey düzeyi faktörlere odaklandığı; 1985-1995 arası yapılan araştırmaların bireyler arası (algılanan yönetici desteği, grup uyumu, tükenmişlik gibi) ve örgüt düzeyi (örgüt kültürü, kişi-örgüt uyumu, cinsiyet kompozisyonu gibi) bağlamsal faktörlerin etkilerini de inceleme konusu yapmaya başladığı belirtilmiştir. 1995 sonrası günümüze kadar uzanan yazın ise stres ve değişimin önemini vurgulamakta; ampirik araştırmalara dayanmakta; bağlamsal faktörlere daha fazla odaklanmakta; 'işten ayrılma' dan ziyade 'ayrılmama' ya yol açan bağlllık ve işe gömülmüşlük gibi faktörleri irdelemekte; zaman faktörünü ve zamana bağl1 olarak gerçekleşen değişmeleri dikkate almakta ve geçmişte tespit edilen ilişkiler konusundaki kavrayışımızı genişletmektedir (Holtom vd., 2008).

Ulusal yazında, personel devri konusunda yapılan araştırmaların dayandığı modellerin incelendiği bir çalışmada (Demirkıran ve Erdem, 2014), personel devrini açıklamaya çalışan modellerin çoğunun ana değişken olarak iş tatmini, örgütsel bağlılık ve örgütsel adalet konularına odaklandıkları belirtilmiştir. Ancak, söz konusu personel devir modelleri, işten ayrılma niyeti olarak tanımlanabilecek bir tutumu her zaman içermemektedir. Yine de bu durum, ulusal yazında neden işten ayrılma niyetinin sıklıkla bu değişkenler ile ilişkisi bağlamında incelendiğini açıklar niteliktedir. Benzer biçimde, uluslararası yazında geliştirilen modellerde de işten ayrılma niyetinin sıklıkla iş tatmini ve örgütsel bağl1lı üzerinden açıklanmaya ve çözümlenmeye çalışıldığ görülmektedir (Halawi, 2014). Diğer yandan, araştırmalar (Steel ve Ovalle, 1984), işten ayrılma niyetinin, işten ayrılma davranışını yordama gücünün, iş tatmini veya örgütsel bağl1liktan çok daha yüksek olduğunu meta-analitik bulgularla desteklemektedir. Tekil araştırmaların tespit ettiği bulguların ötesinde ve bu bulguları sistematik biçimde incelemek suretiyle bütüncül bir model oluşturma çabası ise özellikle ulusal yazında bir eksiklik olarak durmaktadır. Üstelik, işten ayrılma niyetinin, örgütsel davranış yazının bilindik değişkenleriyle sıklıkla ilişkilendirilmesi şaşırtıcı olmasa da işten ayrılma niyetinin en çok ve en az ilişkilendiği değişkenlerin tespit edilmesi; işten ayrılma niyetinin bir nevi aile ağacının çıkarılması; araştırmaya muhtaç alanların tespit edilmesi ve ulusal yazının işten ayrılma niyeti karşısındaki durumunun saptanması ihtiyacı söz konusudur.

$\mathrm{Bu}$ çalı̧̧manın amacı, ulusal örneklemler üzerinde gerçekleştirilen ampirik araştırmalar bağlamında işten ayrılma niyetinin öncüllerini sistematik olarak incelemek ve değerlendirmektir. İșten ayrılma eyleminin en ciddi habercisi olduğuna işaret edilen ve çalışanların, istihdam koşullarından memnuniyetsizliğinin bir dişavurumu olan işten ayrılma niyeti ve kararı, ulusal yazın bağlamında incelendiğinde, 1) işten ayrılma niyetini etkileyen faktörlerin tespiti, 2) işten ayrılma niyetinin çeşitli değişkenlerle ilişkisinin yönünün ve 
gücünün belirlenmesi, 3) ulusal yazında işten ayrılma niyetiyle ilişkilendirilen değişkenlerin uluslararası yazınla benzeşen/ayrışan yönlerinin tespit edilmesi, 4) işten ayrılma niyetinin öncülleri konusunda ulusal bağlama özgü bir model ortaya konması ve çalışmalardaki zayıflık/güçlülüklerin saptanması, 5) işten ayrılma niyetiyle ilgili çalışmalarda sıklıkla kullanılan ölçüm araçlarının ortaya konulması, 6) gelecekte işten ayrılma niyeti üzerine çalışmalar yapacak araştırmacılara bir yol haritası çizilmesi mümkün olabilecektir.

\section{YÖNTEM}

\section{A. Literatür Taraması ve İçleme-Dışlama Kriterleri}

Araştırmanın modeli kapsamında şu sorulara yanıt aranmaktadır:

1) İşten ayrılma niyeti hangi öncül değişkenlerle ilişkilendirilmiştir?

2) İşten ayrılma niyeti, bu öncüllerle nasıl ve ne düzeylerde bir ilişki göstermiştir?

3) Ulusal yazın bağlamında, işten ayrılma niyetini etkileyen kişi/örgüt düzeyi değişkenlerin kümesi nedir ve kuram/pratik açılarından vargıları nelerdir?

Çalışmanın cevap aradığı araştırma problemlerini yanıtlamak üzere Ulakbim TR Dizin, EBSCO Host, Web of Science, ACAR Index ve Google Akademik veri tabanlarında "işten ayrılma niyeti", "işten ayrılma", "intention to leave", "intent to quit", "organizational withdrawal" anahtar sözcüklerini içeren makaleler taranmıştır. Yıl kısıtı konulmaksızın yapılan ilk aramada 2670 çalışma ile karşılaşılmıştır. Ulaşılan yayınların meta-analize dahil edilmesi için a) Çalışmanın ampirik verilere dayanması, b) İşten ayrılma niyeti ile birtakım öncül değişkenler arasındaki ilişkiyi incelemesi, c) Söz konusu ilişkilerin yönüne dair bir varsayımda veya çıkarımda bulunulmuş olması, d) Korelasyon katsayılarının ve örneklem büyüklüklerinin raporlanmış olması, e) Verinin Türkiye bağlamında toplanmış olması, f) Çalışmanın, hakemli bir dergide yayımlanmış olması koşulları baz alınmıştır. Bu kriterler gözetildiğinde, tezler, bildiriler, ödevler ve hakemli dergilerde yayınlanıp yayınlanmadığı tespit edilemeyen çalışmalar elenmiş, kriterlere uygun 192 makale yıllara göre klasörlenmiştir.

Arama sonucunda ulaşılan, çalışma kriterlerini karşılayan ve hakemli dergilerde yayınlandığından emin olunan 192 makaleden bir kısmı, işten ayrılma niyetini ölçümlemediği, Türkiye dışından örneklemler içerdiği veya gerekli ampirik bulguları sunmadığından kapsam dışı kalmıştır. Geriye kalan 176 adet ampirik veriye dayanan çalışma meta-analize dahil edilmek amaciyla kodlama sürecine alınmıştır. $\mathrm{Bu}$ çalışmalardan bir kısmı da aranan istatistiklerin raporlanmamış olması nedeniyle kodlama işlemi sırasında kapsamdan çıkarılmıştır. Bazı çalışmalarda ise aynı verinin ikinci defa kullanıldığı tespit edildiğinden, duplikasyon olmaması açısından çalışmalardan yalnızca biri kodlama sürecine dahil edilmiştir. Kodlama işlemi 119 makale ve 210 veri ile yapılmıştır.

İşten ayrılma niyeti, ulusal yazında yer alan makalelerde iş tatmini, bağl1lık, özdeşleşme, tükenmişlik, iş stresi, duygusal emek, iş performansı gibi değişkenlerle bir arada incelenmiştir. Ayrıca işten ayrılma niyeti, öğrenme motivasyonu (Tolay-Sabuncuoğlu, 2007), örgütsel güven (Seçilmiş ve Kilıç, 2017), psikolojik sözleşme (Mimaroğlu-Özgen ve Özgen, 2010), örgütsel sinizm 
(Bulut ve Hovardaoğlu, 2018), örgüt iklimi (Gündüz-Çekmecelioğlu, 2005), işe gömülmüşlük (Büyükbeşe ve Gökaslan, 2018), etik iklim (Demir, 2018), örgütsel adalet (Özer ve Günlük, 2010), çatışma (Güzel ve Ayazlar, 2014), kariyerizm (Yıldız ve Ayaz-Arda, 2018), dönüşümcü liderlik (Alper-Ay ve Keleş, 2017), etkileşimci liderlik (Tanrıverdi, Akova ve Çif̧̧i, 2016), otantik liderlik (Taşlıyan ve Hirlak, 2016), nepotizm (Bolat, Bolat, Seymen ve Kat1, 2017), sosyal kaytarma (Güçer vd., 2017) örgütsel vatandaşlık (Çelik ve Çıra, 2013), iş-aile ve aile-iş çatışması (Eşitti, 2018), psikolojik sermaye (Erkuş ve Afacan-Fındıklı, 2013), örgütsel sessizlik (Uslu ve Aktaş, 2017), algılanan örgütsel politika (Başar ve Varoğlu, 2016), kişilik (Taslak, 2015), kariyer geleceği (Sökmen ve Aydıntan, 2016), temel benlik değerlendirmesi (Akgündüz ve Akdağ, 2014), psikolojik rahatlık (Yener, 2018), yenilikçi davranış (Eroğlu vd., 2018), insan kaynakları uygulamaları (Gürbüz ve Bekmezci, 2012), birey-örgüt uyumu (Uysal-Irak, 2014), iş yükü (Cerit ve Özdemir, 2016), yatay ve dikey iletişim (Akyüz ve Yılmaz, 2015) gibi çok sayıda başka değişkenlerle de ilişkilendirilmiştir. Bu çalışmalar, söz konusu ilişkileri inceleyen ancak " 5 " eşik değerinin altında kalan verileri teşkil ettiğinden meta-analize uygun bir tablo sunmamaktadır. Bazı çalışmalarda ise birden fazla değişkene ilişkin veri sunulduğundan bu veriler, ayrı birer çalışma gibi düşünülerek toplam çalışma sayısına ilave edilmiştir. Bir değişkenin meta-analize alınması için aynı konuda yapılmış en az 5 çalışma veya 1000 gözlem olması kriteri gözetilmiştir (Atinc vd., 2010). Sonuçta, 71 makale ve bu makalelerden çekilen $\mathrm{k}=150$ tekil veri $(\mathrm{n}=46,020)$ meta-analiz için uygun bulunmuştur. Veri toplama sürecine ilişkin ayrıntılı akış diyagramı Şekil 1'de sunulmuştur. 


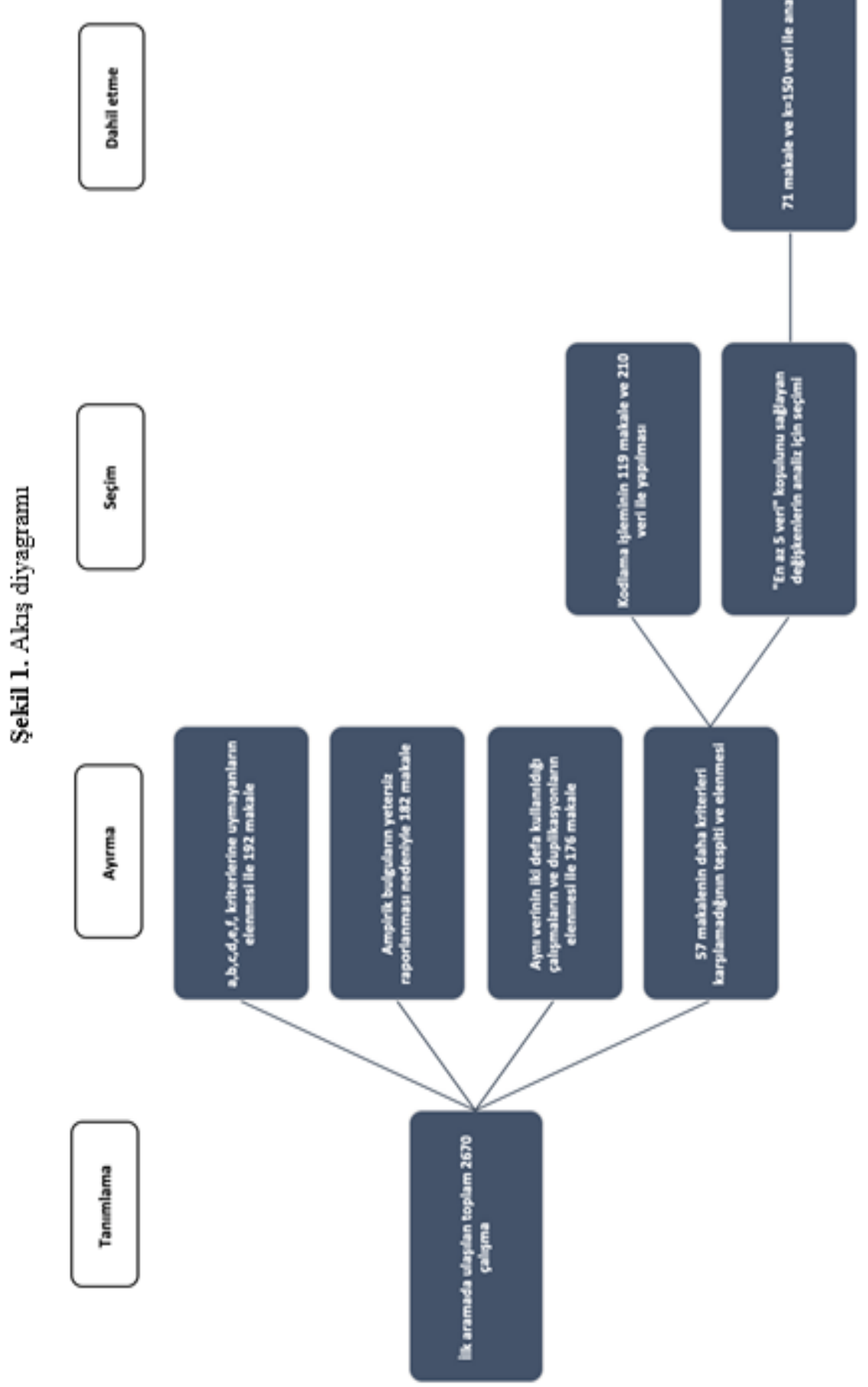




\section{B. Analiz}

Hunter ve Schmidt'in (2004) psikometrik meta-analiz yönteminin benimsendiği çalışmada CMA meta-analiz programı kullanılmıştır. Bireysel çalışmalardan elde edilen korelasyonlar, işten ayrılma niyeti (IAN)-iş tatmini, İAN-duygusal bağl1lık, İAN-örgütsel bağll1ık (toplam), İAN-devam bağl11lı̆g, İAN-algılanan örgütsel destek, İAN-normatif bağlilık, İAN-özdeşleşme, İAN-iş stresi, İAN-duygusal tükenme, İAN-yüzeysel rol yapma, İAN-duyarsızlaşma, İAN-kişisel başarıda düşme, İAN-derinden rol yapma, İAN-tükenmişlik (toplam) ve İAN-iş performansı olmak üzere on beş farklı meta-analizde değerlendirilmiştir.

Hunter ve Schmidt'in (2004) psikometrik meta-analiz yöntemi çerçevesinde, korelasyon değerleri üzerinden işlem ve yorumlar yapılsa da örtük bir nedensellik varsayımı söz konusudur. İlişkilerin istatistiki olarak anlamlılığına karar vermek için etki büyüklüğüne ilişkin güven aralıklarının (confidence inverval) alt ve üst limitlerinin sıfır değerini içermemesi kriteri baz alınmıştır. Yine, etki büyüklüklerinin gücünü yorumlamada Cohen (1992) tarafindan referans gösterilen eşik değerler gözetilmiş; 0,50 ve üzeri korelasyonlar yüksek etki, 0,30 düzeyi korelasyonlar orta düzey etki ve 0,10 düzeyi korelasyonlar zayıf etki olarak değerlendirilmiștir (Cohen, Manion, \& Morrison, 2007).

Korelasyon değerleri ve örneklem büyüklükleri üzerinden gerçekleştirilen analizler incelenirken, toplam çalışma sayısı $(\mathrm{k})$, toplam örneklem büyüklüğü $(\mathrm{N})$, Fisher's Z değeri, $\% 95$ güven aralı̆̆ 1 için korelasyon değerinin alt ve üst limitleri, heterojenlik testine ilişkin $\mathrm{Q}$ değeri, serbestlik derecesi ve $\mathrm{p}$ değerleri dikkate alınmıştır.

Heterojenlik testi sonucunun sabit etki modeli veya rassal etki modeli arasında seçim yapmada kullanılabileceği önerilmişse de bu çalışmada, Field ve Gillett' in (2010) ifadeleri kılavuz alınmıştır. Sosyal bilimlerin doğası gereği metaanalitik çalışmalarda rassal etkiler modelinin kullanılması gerektiği yönündeki önerilerine ithafen, tüm meta-analizlerde rassal etki modeline göre sonuçlar raporlanmiştır.

\section{Araştırmanın Bulguları ve Sonuçları}

Meta-analiz kapsamına giren çalışmaların künyeleri ve araştırma değişkenleri Tablo 1'de sunulmuştur. Makaleler, tarihsel olarak 2003-2018 y1lları arasında yayımlanmış olup, en az 1 ve en fazla 5 yazarlıdır. Örneklem sayısı açısından en küçük 39, en büyük 1085 gözlem birimi bulunmaktadır. İş tatmini 29 veri, duygusal bağl1lık 16 veri, örgütsel bağl1lık (toplam ölçek) 12 veri, devam bağl1lığ1 11 veri, algilanan örgütsel destek 11 veri, normatif bağlilık 10 veri, özdeşleşme 10 veri, iş stresi 10 veri, duygusal tükenme 8 veri, yüzeysel rol yapma 6 veri, duyarsızlaşma 6 veri, kişisel başarıda düşme 6 veri, derinden rol yapma 5 veri, tükenmişlik ve iş performansı 5 'er veri üzerinden İAN niyeti ile ilişkisi bağlamında meta-analize tabi tutulmuştur.

İşten ayrılma niyetinin ulusal yazın bağlamında en çok ilişkilendirildiği değişkenin iş tatmini olduğu tespit edilmiştir. Ancak, bireysel çalışmalar bu ilişkinin negatif yönlülüğu konusunda hemfikir olsa da gücü konusunda bir 
tutarlılık bulunmamaktadır. Tablo 2 'de yer alan analiz bulgularında görüldüğü üzere, 29 çalışma ve 8015 gözlem birimi ile gerçekleştirilen meta-analizde, iş tatmini ile işten ayrılma niyeti arasında orta-yüksek düzeylerde negatif yönlü ilişki tespit edilmiştir $(\mathrm{EB}=-0,478, \mathrm{p}<0,00)$. Örgütsel bağl1lık ve alt boyutlarının işten ayrılma niyeti ile ilişkisine bakıldığında, tüm alt boyutlar ve toplam ölçek negatif yönde ilişkili olmakla birlikte, en yüksek ilişki duygusal bağlılık (EB=$0,462, \mathrm{p}<0,00)$ ve en düşük ilişki devam bağl1lı̆g $(\mathrm{EB}=-0,082, \mathrm{p}<0,00)$ alt boyutlarında bulgulanmıştır. 
Tablo 1. Çalışmaların künyesi

\begin{tabular}{|c|c|c|c|c|c|}
\hline Değișsenler & Yazar ve yilı & n & Değișkenler & Yazar ve yılı & $\mathrm{n}$ \\
\hline \multirow{29}{*}{$\begin{array}{l}\text { İş tatmini } \\
(29)\end{array}$} & Gündüz-Cekmecelioğlu, 2005 & 130 & \multirow{10}{*}{$\begin{array}{c}\text { Normatif } \\
\text { bağlılık (10) }\end{array}$} & Wasti, 2003 & 914 \\
\hline & Poyraz, \& Kama, 2008 & 211 & & Demircan-Cakar, \& Ceylan, 2005 & 84 \\
\hline & Gül, Oktay, \& Gökçe, 2008 & 87 & & Gündüz-Çekmecelioğlu, 2005 & 130 \\
\hline & Yazıcıoğlu, 2009 & 332 & & Tolay-Sabuncuoğlu, 2007 & 600 \\
\hline & Özer, \& Günlük, 2010 & 240 & & Günlük, Özer, \& Özcan, 2013 & 1085 \\
\hline & Yücel, \& Demirel, 2013 & 109 & & Akyüz, \& Eşitti, 2015 & 450 \\
\hline & Erkuş, \& Afacan-Fındıklı, 2013 & 572 & & Taslak, 2015 & 120 \\
\hline & Kitapçı, Kaynak, \& Ökten, 2013 & 516 & & Mumcu, \& Alıcı, 2016 & 136 \\
\hline & Günlük, Özer, \& Özcan, 2013 & 1085 & & Uștu, \& Tümkaya, 2017 & 712 \\
\hline & Akbolat, Yılmazer, \& Tutar, 2014 & 253 & & Çelik, \& Yıldız, 2018 & 667 \\
\hline & Yıldız, 2014 & 142 & \multirow{10}{*}{ Özdeşleşme (10) } & Turunç, \& Çelik, 2010 & 172 \\
\hline & Yüksel, \& Yüksel, 2014 & 30 & & Afacan-Fındıklı, 2014 & 341 \\
\hline & Tekingündüz, Top, \& Seçkin, 2015 & 196 & & Tuna, \& Yeșiltaş, 2014 & 385 \\
\hline & Akova, Emiroğlu, \& Tanrıverdi, 2015 & 262 & & Akyüz, \& Yılmaz, 2015 & 122 \\
\hline & Anafarta, 2015 & 245 & & Topçu, \& Basım, 2015 & 421 \\
\hline & Erdilek-Karabay, 2015 & 206 & & Sökmen, \& Şimşek, 2016 & 147 \\
\hline & Taslak, 2015 & 120 & & Tolukan, Şahin, \& Koç, 2016 & 204 \\
\hline & Tekingündüz, \& Kurtuldu, 2015 & 208 & & Çınar, Karcıoğlu, \& Akdaş, 2016 & 286 \\
\hline & Zincirkıran, Mat-Çelik, Ceylan, \& Emhan, 2015 & 254 & & Çelik, \& Yıldız, 2018 & 667 \\
\hline & Çınar, Karcıoğlu, \& Akdaş, 2016 & 286 & & Uzun, 2018 & 197 \\
\hline & Sökmen, \& Aydıntan, 2016 & 196 & \multirow{10}{*}{ İşstresi (10) } & Gül, Oktay, \& Gökçe, 2008 & 87 \\
\hline & Sevinç-Altaș, \& Kuzu, 2016 & 107 & & Akova, Emiroğlu, \& Tanrıverdi, 2015 & 262 \\
\hline & Karaca, Biçkes, Çakı, \& Karaduman, 2017 & 39 & & Erdilek-Karabay, 2015 & 206 \\
\hline & Sökmen, \& Ceyhun-Sezgin, 2017 & 362 & & Tekingündüz, \& Kurtuldu, 2015 & 208 \\
\hline & Aslan, \& Uyar, 2018 & 300 & & Turunç, \& Avc1, 2015 & 293 \\
\hline & Bulut, \& Hovardaoğlu, 2018 & 283 & & Tekingündüz, Top, \& Seçkin, 2015 & 196 \\
\hline & Çankır, \& Şahin, 2018 & 355 & & Zincirkıran, Mat-Çelik, Ceylan, \& Emhan, 2015 & 254 \\
\hline & Yücel, \& Koçak, 2018 & 308 & & Çelik, \& Yıldız, 2016 & 667 \\
\hline & Eșitti, 2018 & 581 & & Sökmen, \& Şimşek, 2016 & 147 \\
\hline \multirow{16}{*}{$\begin{array}{c}\text { Duygusal } \\
\text { bağlılık (16) }\end{array}$} & Wasti, 2003 & 914 & & Yavuz, \& Akca, 2018 & 401 \\
\hline & Demircan-Çakar, \& Ceylan, 2005 & 84 & \multirow{8}{*}{$\begin{array}{l}\text { Duygusal } \\
\text { tükenme (8) }\end{array}$} & Sağlam-Arı, Bal, \& Çına-Bal, 2010 & 80 \\
\hline & Gündüz-Çekmecelioğlu, 2005 & 130 & & Aslan, 2014 & 151 \\
\hline & Tolay-Sabuncuoğlu, 2007 & 600 & & Aslan, \& Etyemez, 2015 & 200 \\
\hline & Gürbüz, \& Bekmezci, 2012 & 259 & & Taslak, 2015 & 120 \\
\hline & Günlük, Özer, \& Özcan, 2013 & 1085 & & Karakaş, 2017 & 536 \\
\hline & Giray, \& Şahin, 2014 & 341 & & Alper-Ay \& Türkdoğan, 2018 & 200 \\
\hline & Gündüz-Çekmecelioğlu, 2014 & 220 & & Tanrıverdi, Koçaslan, \& Osmanoğlu-Taştan, 2018 & 243 \\
\hline & Akyüz, \& Eşitti, 2015 & 450 & & Yürür, \& Ünlü, 2011 & 109 \\
\hline & Taslak, 2015 & 120 & & Beğenirbaş, \& Çalışkan, 2014 & 403 \\
\hline & Mumcu, \& Alıcı, 2016 & 136 & & Çelik, \& Yıldız, 2016 & 667 \\
\hline & Sevinç-Altaş, \& Kuzu, 2016 & 107 & Yüzeyæl & Karakaş, 2017 & 536 \\
\hline & Kartopu, \& Gürbüz, 2016 & 410 & rol yapma (6) & Alper-Ay \& Türkdoğan, 2018 & 200 \\
\hline & Uștu, \& Tümkaya, 2017 & 712 & & Yeşil, \& Mavi, 2018 & 300 \\
\hline & Çelik, \& Yıldız, 2018 & 667 & & Yürür, \& Ünlü, 2011 & 109 \\
\hline & Koçak, \& Yücel, 2018 & 236 & & Sağlam-Arı, Bal, \& Çına-Bal, 2010 & 80 \\
\hline & Poyraz \& Kama, 2008 & 211 & & Aslan, 2014 & 151 \\
\hline & Sağlam-Arı, Bal, \& Çına-Bal, 2010 & 80 & Duyarsyjasma (6) & Aslan, \& Etyemez, 2015 & 200 \\
\hline & Demir, 2012 & 282 & | Duyarsizaş̧ma (6) & Karakaş, 2017 & 536 \\
\hline & Yıldız, Yalavaç, \& Meydan, 2013 & 190 & & Alper-Ay \& Türkdoğan, 2018 & 200 \\
\hline & Tekingündüz, \& Kurtuldu, 2015 & 208 & & Tanrıverdi, Koçaslan, \& Osmanoğlu-Taștan, 2018 & 243 \\
\hline bağlılık (toplam. & Zincirkıran, Mat-Çelik, Ceylan, \& Emhan, 2015 & 254 & & Sağlam-Arı, Bal, \& Çına-Bal, 2010 & 80 \\
\hline (1) & Ekmekçioğlu, \& Sökmen, 2016 & 153 & & Aslan, 2014 & 151 \\
\hline & Sökmen, \& Şimşek, 2016 & 147 & Kişisel başarıda & Aslan, \& Etyemez, 2015 & 200 \\
\hline & Yüce, \& Kavak, 2017 & 392 & düşme (6) & Karakaş, 2017 & 536 \\
\hline & Bulut \& Hovardaoğlu, 2018 & 283 & & Alper-Ay \& Türkdoğan, 2018 & 200 \\
\hline & Demir, 2018 & 259 & & Tanrıverdi, Koçaslan, \& Osmanoğlu-Taștan, 2018 & 243 \\
\hline & Gökaslan, 2018 & 210 & & Beğenirbaş, \& Çalışkan, 2014 & 403 \\
\hline & Wasti, 2003 & 914 & & Karakaş, 2017 & 536 \\
\hline & Demircan-Cakar, \& Ceylan, 2005 & 84 & Derinden & Yürür, \& Ünlü, 2011 & 109 \\
\hline & Gündüz-Çekmecelioğlu, 2005 & 130 & & Alper-Ay, \& Türkdoğan, 2018 & 200 \\
\hline & Tolay-Sabuncuoğlu, 2007 & 600 & & Yeșil, \& Mavi, 2018 & 300 \\
\hline & Günlük, Özer, \& Özcan, 2013 & 1085 & & Yıldız, Yalavaç, \& Meydan, 2013 & 190 \\
\hline baălı ăı (11) & Akyüz, \& Eşitti, 2015 & 450 & & Çetin, Güleç, \& Kayasandık, 2015 & 168 \\
\hline & Taslak, 2015 & 120 & (tonlam 5) & Bozacı, Çiftçi, \& Gürer, 2018 & 100 \\
\hline & Mumcu, \& Alıcı, 2016 & 136 & & Yücel, \& Koçak, 2018 & 308 \\
\hline & Kartopu, \& Gürbüz, 2016 & 410 & & Yavuz, \& Akca, 2018 & 401 \\
\hline & Uștu, \& Tümkaya, 2017 & 712 & & Yıldız, Savcı, \& Kapu, 2014 & 130 \\
\hline & Çelik, \& Yıldız, 2018 & 667 & & Gündüz-Çekmecelioğlu, 2014 & 220 \\
\hline & Turunç, \& Çelik, 2010 & 172 & IŞ & Tekingündüz, Top, \& Seçkin, 2015 & 196 \\
\hline & Demir, 2012 & 282 & & Sevinç-Altaş, \& Kuzu, 2016 & 107 \\
\hline & Afacan-Fındıklı, 2014 & 341 & & Alper-Ay, \& Türkdoğan, 2018 & 200 \\
\hline & Giray, \& Şahin, 2014 & 341 & & & \\
\hline & Anafarta, 2015 & 245 & & & \\
\hline Algilanan & Turunç, \& Avc1, 2015 & 293 & & & \\
\hline ơrgütsel destek (11) & Ekmekçioğlu, \& Sökmen, 2016 & 153 & & & \\
\hline & Öztürk, \& Eryeşil, 2016 & 134 & & & \\
\hline & Bakan, Erşahan, Büyükbeșe, Okumuş, \& Akmeşe, 2017 & 360 & & & \\
\hline & Koçak, \& Yücel, 2018 & 236 & & & \\
\hline & Uzun, 2018 & 197 & & & \\
\hline
\end{tabular}


11 çalışma üzerinden gerçekleştirilen algılanan örgütsel destek ve İAN meta-analizi güçlü düzeyde negatif bir ilişki ortaya koymaktadır $(\mathrm{EB}=-0,518$, $\mathrm{p}<0,00)$. Özdeşleşme-İAN arasındaki negatif yönlü ilişki ise zayıf düzeydedir $(\mathrm{EB}=-0,278, \mathrm{p}<0,00)$. İş stresi, İAN ile orta düzeylerde ve pozitif yönlü ilişkilenmiştir $(\mathrm{EB}=0,395, \mathrm{p}<0,00)$. Tükenmişlik ve alt boyutlarının İAN ile ilişkisini inceleyen meta-analizlere göre, her biri pozitif yönde ilişkilenmek kaydıyla, en yüksek korelasyon duygusal tükenme $(\mathrm{EB}=0,630)$ ve en düşük korelasyon kişisel başarıda düşme $(\mathrm{EB}=0,115, \mathrm{p}<0,00)$ alt boyutlarında tespit edilmiştir. Duygusal tükenme-İAN arasında güçlü düzeyde ilişki görülse de kişisel başarıda düşme boyutu-İAN arasındaki ilişki ihmal edilebilir düzeydedir. Duygusal emeğin alt boyutları ve İA arasındaki ilişkilere bakıldığında, yüzeysel rol yapma-İAN arasında pozitif yönde ve orta düzeyde $(\mathrm{EB}=0,358, \mathrm{p}<0,00)$ ilişki görülürken, derinden rol yapma-İAN arasında negatif yönde ve çok zayıf $(\mathrm{EB}=-$ $0,107, \mathrm{p}<0,00)$ ilişki olduğu görülmektedir. İş performansi-İAN meta-analizi 5 çalışma ile gerçekleştirilse de "1000 gözlem" eşik değerinin altında kalınmıştır. $\mathrm{Bu}$ sınırlılık göz önünde bulundurulmakla birlikte, iş performansı ve İAN arasındaki negatif yönlü ilişkinin zayıf düzeyde olduğu görülmektedir ( $\mathrm{EB}=-$ $0,133, \mathrm{p}<0,00)$.

Tablo 2. İAN Öncüllerinin Meta-Analizi ve Etki Büyüklükleri

\begin{tabular}{|c|c|c|c|c|c|c|c|}
\hline \multirow[b]{2}{*}{ Bağımlı değișkenler } & \multirow[b]{2}{*}{$\mathrm{k}$} & \multirow[b]{2}{*}{$\mathrm{N}$} & \multicolumn{2}{|c|}{ EB'nin $\% 95$ güven aralığ } & \multicolumn{3}{|c|}{ Heterojenlik testi } \\
\hline & & & EB* & Alt-üst sınır & $\begin{array}{c}\mathrm{Q} \\
\text { değeri }\end{array}$ & sd & $\mathrm{p}$ \\
\hline İş tatmini & 29 & 8015 & $-0,478$ & $(-0,561)-(-0,386)$ & 712,388 & 28 & 0,000 \\
\hline Duygusal bağlılık & 16 & 6471 & $-0,462$ & $(-0,562)-(-0,362)$ & 231,730 & 15 & 0,000 \\
\hline Örgütsel bağll1ık & 12 & 2669 & $-0,362$ & $(-0,485)-(-0,240)$ & 110,331 & 11 & 0,000 \\
\hline Devam bağl1 $\operatorname{liğ}_{1}$ & 11 & 5308 & $-0,082$ & $(0,002)-(0,035)$ & 171,068 & 10 & 0,000 \\
\hline Algılanan örgütsel destek & 11 & 2754 & $-0,518$ & $(-0,637)-(-0,398)$ & 99,371 & 10 & 0,000 \\
\hline Normatif bağl1lık & 10 & 4898 & $-0,333$ & $(-0,454)-(-0,213)$ & 147,427 & 9 & 0,000 \\
\hline Özdeşleşme & 10 & 2942 & $-0,278$ & $(-0,327)-(-0,228)$ & 17,901 & 9 & 0,036 \\
\hline İşs stresi & 10 & 2721 & 0,395 & $(0,222)-(0,545)$ & 223,268 & 9 & 0,000 \\
\hline Duygusal tükenme & 8 & 1639 & 0,630 & $(0,493)-(0,768)$ & 50,785 & 7 & 0,000 \\
\hline Yüzeysel rol yapma & 6 & 2215 & 0,358 & $(0,063)-(0,133)$ & 649,002 & 5 & 0,000 \\
\hline Duyarsızlaşma & 6 & 1410 & 0,515 & $(0,440)-(0,590)$ & 9,046 & 5 & 0,107 \\
\hline Kişisel başarıda düşme & 6 & 1410 & 0,115 & $(0,244)-(0,474)$ & 214,715 & 5 & 0,000 \\
\hline Derinden rol yapma & 5 & 1548 & $-0,107$ & $(-0,172)-(-0,042)$ & 6,226 & 4 & 0,183 \\
\hline Tükenmişlik & 5 & 1167 & 0,520 & $(0,424)-(0,616)$ & 10,093 & 4 & 0,039 \\
\hline İş performansı & 5 & 853 & $-0,133$ & $(-0,220)-(-0,044)$ & 6,913 & 4 & 0,141 \\
\hline
\end{tabular}

$k=$ analize dahil edilen çalışmaların toplamı, $N=$ analize dahil edilen çalışmalardaki toplam örneklem saylsl, EB=etki büyüklügü, sd=serbestlik derecesi, $p=$ anlamlllık düzeyi, *tüm etki büyüklükleri \%95 güven aralığında anlamlıdır. 
Meta-analiz çalışmalarının en ciddi sınırlılı̆̆ını oluşturan ve yazında mevcut olan tüm çalışmalara ulaşamama riskinin bir göstergesi kabul edilen yayın yanlılığı sorunsalını aşmak üzere Tau katsayısının anlamlılığı incelenmiştir. "Çekmecede unutulan yayınlar" sorunsalı olarak adlandırılan (Rosenthal, 1979) olguya göre, istatistiksel olarak anlamlı bulgular üretmeyen çalışmalar çekmecelere mahkum edilmekte ve basılı araştırmalar istatistiksel olarak anlamlı sonuçlar lehine yanlılık göstermektedir. Sonuçta bu durum, meta-analiz çalışmalarının da yanlılığına yol açmaktadır.

Tablo 3. Sira korelasyon testi bulguları

Sira korelasyon testi bulguları

\begin{tabular}{lccc}
\hline Değişkenler & $\mathrm{N}$ & Kendall's Tau & $\mathrm{p}$ \\
\hline İş tatmini ile İAN & 29 & $-0,012$ & 0,9252 \\
Duygusal bağlılık ile İAN & 16 & 0,017 & 0,9283 \\
Örgütsel bağlılık ile İAN & 12 & $-0,151$ & 0,4928 \\
Devam bağlılığı ile İAN & 11 & $-0,090$ & 0,6970 \\
Algılanan örgütsel destek ve İAN & 11 & $-0,036$ & 0,8762 \\
Normatif bağlılık ile İAN & 10 & 0,200 & 0,4208 \\
Özdeşleşme ve İAN & 10 & $-0,066$ & 0,7884 \\
İş stresi ve İAN & 10 & $-0,111$ & 0,6547 \\
Duygusal tükenme ve İAN & 8 & $-0,321$ & 0,2655 \\
Yüzeysel rol yapma ve İAN & 6 & 0,467 & 0,1884 \\
Duyarsızlaşma ve İAN & 6 & $-0,666$ & 0,0602 \\
Kişisel başarıda düşme ve İAN & 6 & $-0,266$ & 0,4523 \\
Derinden rol yapma ve İAN & 5 & 0,600 & 0,1416 \\
Tükenmişlik ve İAN & 5 & 0,400 & 0,3271 \\
İş performansı ve İAN & 5 & 0,000 & 1,000 \\
\hline
\end{tabular}

Tablo 3'te görüldüğü üzere, meta-analiz çalışmalarının en ciddi kısıtlılıklarından olan yayın yanlılığı sorunsalını sınamak ve kontrol altına almak üzere Begg ve Mazumdar'ın (1994) sura korelasyon testi sonucu incelenmiştir. Kendall Tau katsayısının istatistiksel olarak anlamlı olmasının, yayın yanlılığının (Field ve Gillett, 2010) bir göstergesi olduğu değerlendirilmiştir.

Tüm meta-analizlerde Tau katsayısının $\mathrm{p}$ değeri \%95 güven aralığında 0,05 eşiğinin üzerinde değerler almıştır. Buna göre, bu araştırmaya konu olan meta-analizlerde yayın yanlılığı probleminin belli ölçüde kontrol altına alındığı söylenebilir.

\section{TARTIŞMA VE ÖNERILLER}

Prof. Dr. Nusret Ekin, 1960 yılında kaleme aldığ "Memleketimizde Iş̧̧̧i Devri Mevzuunda Yapılan Araştırmalar ve Ortaya Koydukları Neticeler" başlıklı eserinde, devlet eliyle hızla sanayileşmeye çabalayan Genç Cumhuriyetin işgören devri konusunda yaşadığ 1 sorunların boyutunu Sümerbank ve Etibank raporları üzerinden sayısallaştırırken, bir taraftan da güncelliğini halen koruduğunu gördüğümüz şu tespitleri yapmaktadır:

...1940'dan beri elimizde bulunan raporların hemen hepsinde, işçi meseleleri içinde işçi devri problemi bilhassa, şikâyet mevzuu olan ve en ehemmiyetli hususu teşkil etmektedir. Bu raporlarda işçi devri meselesi, daima ilk önce temas edilen, sebepleri araştırılan ve azaltılması hususunda hâl çareleri derpiş edilen bir problem mahiyeti göstermektedir... Bu 
vaziyet, işçi mevzuunu ele alınca en evvel işçiyi müesseseye bağlıyacak çare üzerinde durmayı icap ettirmektedir, işçi müesseseye bağlandıktan sonradır ki, nazarî olarak tesbit edilecek kadro bir kıymet ifade edecektir. Yine bu bağlılık noksanıdır ki işçiyi devam bahsinde de alâkasız birakmaktadır. (s.135)

Holtom ve arkadaşları (2008), işten ayrılma ve işte kalma yazınının dünü, bugünü ve geleceği üzerine incelemeler yaptıkları çalışmalarında, yarım asıra yayılmış ve o tarih itibariyle sayıları 1500'ün üzerindeki akademik çalışmaya rağmen konunun güncelliğini halen koruduğunu ve yeni çalışmalara ihtiyaç duyulduğunu belirtmişlerdir. Normal koşullar altında, ekonomik ve demografik göstergelerin işten ayrılma/ayrılmama kararlarını düzenleyen başat gösterge olacağı yönündeki sağduyu ve sezgiye dayalı önermelerin bireylerin işten ayrılma kararları üzerinde sanıldığı kadar etkili olmadığı ve işsizlik rakamlarının zayıf açıklama gücü uzun yıllar önce yapılan çalışmalarda ortaya konmuştur (Carsten ve Spector, 1987; Hulin vd., 1985). İşten ayrılmaların ne zaman fonksiyonel, kaçınılabilir ve faydalı olduğu ile ne zaman aksinin geçerli olduğu, somut işten ayrılma verileri ile değil; işten ayrılmaya giden süreçte izlenen birey düzeyi göstergeler ile mümkün göründüğünden, konunun güncelliğini korumaya devam edeceği söylenebilir.

Mevcut çalışmanın bulgularına göre işten ayrılma niyeti, ulusal yazında kendisiyle siklıkla bir arada değerlendirilen değişkenlerden duygusal tükenme, algılanan örgütsel destek ve duyarsızlaşma dışında hiçbiri ile çok güçlü düzeyde ilişkili değildir. Çalışmaya konu olan değişkenlerin işten ayrılma niyetiyle ilişkisinin gücü bağlamında negatif uçta algılanan örgütsel destek, pozitif uçta ise duygusal tükenme yer almaktadır. Çalışanların, işten ayrılma niyetlerini yatıştırmak açısından yöneticilerine/örgütlerine/iş arkadaşlarına güven duygularından hangisinin daha ağır bastığını tespit etmek için ise daha detaylı alt boyut analizlerine ihtiyaç duyulmaktadır. Genel bir değerlendirme yapılacak olursa, diğer koşullar sabit tutulmak kaydıyla, örgüte güvenin işten ayrılma niyetini azaltacağı söylenebilir. Duygusal tükenmenin işten ayrılma niyeti ile güçlü ilişkisi, uç düzeyde bir geri çekilme davranışı (withdrawal behavior) örneği olan tükenmiş̧liğin beklendik bir sonucu olarak değerlendirilebilir. Bu noktada, duygusal tükenmenin kaynağının iş kaynaklı mı özel yaşam kaynaklı mı olduğu konusu gündeme gelmektedir. İşten ayrılma niyetinin taşma etkisiyle özel yaşamdan kaynaklanması durumunda örgütsel alanda alınacak tedbirlerin hükmü kalmayabilir. Ancak, sebep örgüt ve iş kaynaklı olduğu ölçüde, duygusal tükenmenin işten ayrılma niyetiyle güçlü pozitif ilişkisi, işten ayrılmaması arzulanan çalışanları hangi açıdan "tüketmemek" gerektiğine dair fikir sunmaktadır. İş performansının işten ayrılma niyetinden olumsuz etkileneceği yönündeki yaygın görüş ise meta-analitik bulgulara göre çok düşük bir geçerlilik taşımaktadır. Çünkü, iş performansı ile yapılan analizler, anlamlı olsa da çok düşük-ihmal edilebilir bir ilişki göstermektedir. Örgütsel bağlllığın boyutlandırılarak incelendiği çalışmalar üzerine yapılan analiz, devam bağl1lı̆̆nın işten ayrılma niyeti ile ihmal edilebilir düzeydeki ilişkisi veri iken, 
özellikle duygusal ve normatif bağlılığın önemine işaret etmektedir. Belki de duygusal bağlılı̆g yüksek çalışanların işe, yöneticilerine, iş arkadaşlarına, örgüte ve mesleğe ilişkin algıladıkları problemlere toleransları yükselmekte ve başa çıkma kapasiteleri artmakta; bu durum ise işe alma-terfi gibi süreçlerde ilgililere bir mesaj niteliği taşımaktadır. Duygusal tükenme ve duyarsızlaşmanın işten ayrılma niyeti ile ilişkisinin gücüne karşın, kişisel başarıda düşme boyutunun ihmal edilebilir düzeydeki ilişkisi de iş performansı-İAN arasındaki zayıf ilişkiyi destekler niteliktedir. Başarı ve performansın, işten ayrılma niyetiyle - yaygın biçimde inanılanın aksine - yüksek oranda ilişkili olmaması, ancak diğer taraftan, kişinin duygusal tükenmişliği, duyarsızlaşması ve tatminsizliği ile yüksek düzeyde ilişkilenmesi, işten ayrılma niyetinin duyuşsal olarak kişinin kendisine zarar veren süreçlerden beslendiği ve böylesi bir nitelik taşıdığı şeklinde de yorumlanabilecektir.

Kullanılan ölçüm araçlarına bakıldığında, işten ayrılma niyetinin genellikle tek boyut olarak işlemleştirildiği görülmektedir: 31 defa kullanılan Cammann vd. (1979), 3 madde tek boyut; 20 defa kullanılan Wayne vd. (1997), 5 madde veya 3 madde tek boyut; 19 defa kullanılan Bluedorn (1982) 4 madde veya 3 madde tek boyut; 9 defa kullanılan Rusbelt vd. (1988), 4 madde veya 3 madde tek boyuttan oluşan ölçekler, en sık kullanılan ölçüm araçları olarak ortaya çıkmaktadır. Chiu vd. (2005), 4 madde tek boyut, Walsh vd. (1985), 5 madde tek boyut, Seashore vd. (1982) 3 madde tek boyut, Hanisch ve Hulin (1990; 1991), 3 madde tek boyut, Hom vd. (1984), 4 madde tek boyut, Mowday vd. (1984), 1 madde tek boyut, Rosin ve Korabik (1995), 4 madde tek boyut, Polat ve Meydan (2009) 5 madde tek boyut, Ganesan ve Weitz (1996), 5 madde tek boyut, Rosin ve Korabik (1995), 4 madde tek boyut, Tak ve Çiftçioğlu (2009), 5 madde tek boyut, Bulut (2017), 7 madde tek boyut, Karakuş vd. (2014), 4 madde tek boyut ölçekler, kullanılan diğer ölçüm yöntemlerinden bazılarıdır. Bu ölçekler, 7'li Likert ölçeğindeki iki istisnai çalışma haricinde (Wasti, 2003; Demircan-Çakar ve Ceylan, 2005), her zaman 5'li Likert tipi ölçekle katılımcılara uygulanmıştır. Kamu, özel sektör ve ikisinin karmasından oluşan örneklemler, sağlık-eğitimotomotiv-turizm-bankac1lık-savunma sanayi-üniversite/eğitim-yerel yönetimler gibi geniş bir yelpazeye dağılmaktadır.

İşten ayrılma niyeti konusunda yapılan çalışmalarda rastlanan birtakım normatif, taklitçi veya zorlayıcı eşbiçimlilikler dikkatten kaçmamaktadır. Araştırmaların büyük bir kısmında işten ayrılma niyeti ölçümlenirken kolayda örnekleme yöntemi kullanılmıştır. Kullanılan ölçekler ise farklı araştırmacılar tarafından geliştirilmiş olsa dahi, özünde çalışana "yakın zamanda bu işi bırakmayı düşünüyor musunuz?" sorusunu yönelten birkaç ifadeli, kısa ve tek boyutlu ölçeklerdir. Bu ölçeklerin ve yapılan araştırmaların işten ayrılma niyeti ile mesleği bırakma veya başka bir mesleğe transfer olma düşüncesi arasındaki ayrımı gözden kaçırdığı ayrıca dikkat çekmektedir. Diğer taraftan, bu çalışma kapsamında gerçekleştirilen meta-analizlerin tekil verilerinden hiçbiri çok düzeyli veya boylamsal ölçümler içermemektedir. Diğer bir ifadeyle, işten ayrılma niyeti ile çeşitli değişkenler arasında incelenen ilişkiler, genellikle çalışanın bir defalık 
ifadelerine dayanmaktadır. İşten ayrılma niyeti konusundaki beyanların doğrudan çalışanın şahsından toplanması rasyonel bir yaklaşım olarak görülse de yönetici ve akran değerlendirmeleri ile farklı zamanlarda yapılacak değerlendirmelerin farklı sonuçlar ortaya koyması ihtimali soru işareti olarak durmaktadır. Ölçek kullanımlarındaki veya atıflarındaki hatalar ise dikkat çeken bir diğer konudur. Aynı yazarların aynı çalışmalarına atıfla kullanılan ölçeklerin, çalışmalar arasında farklılık gösterdiği, bazen madde sayısının farklılaştı̆̆ 1 ve atıfların tarihlerinde yanlışlıklar yapıldığg görülmektedir.

İşten ayrılma niyetinin sonuç değişkeni olarak kullanıldı̆̆ı çok sayıda çalışma olmakla birlikte, işten ayrılma niyetinin gerçek işten ayrılma davranışı ya da performans gibi maddi ve somut çıktılar üzerindeki etkisinin araştırıldığ çalışma yok denecek kadar azdır. Ulusal yazın, bir çalışanın yoğun düzeylerde işten ayrılma niyeti olsa dahi bunun gerçek işten ayrılma davranışı ile sonlanmayacağı ihtimali karşısında sessizdir ve işten ayrılma niyetini mümkün olan en büyük felaket senaryosu şeklinde ele alarak, yöneticilere, insan kaynakları yetkililerine ve araştırmacılara farazi ve bazen de araştırmaların bulgularını aşan öneriler ile tavsiyeler sunabilmektedir. Bu noktada, işten ayrılma niyetinin işten ayrılma davranışının ancak ve ancak bir öncülü olduğu; örgütle çalışan arasındaki ilişkinin bitmesi şeklinde etkiler doğurmama olasılığı karşısında ihtiyatlı davranmak gerekmektedir. Modelleme, analiz ve yorum yapılırken, iş gücü piyasalarının ve ekonominin güncel durumu, ücretler düzeyi, alternatif işlerin varlığı gibi dışsal faktörlerin dikkate alınması bu anlamda önem arz etmektedir. Nitekim, işgören devrine yol açan nedenler arasında kişi-iş uyumu, iş ilişkilerinin öngörülebilirliği, potansiyel iş alternatifleri, ücretler, iletişim becerisi, örgütün merkezileşme düzeyi, genel ekonomik koşullar, pazarın durumu, işin maliyetleri, sektör, stres, iş güvenliği, zaman çatışması, ailevi yükümlülükler, eğitim firsatları, özerklik düzeyi, terfi imkanları, sosyal destek, karar verme yetkisi, kişisel gelişim fırsatları, kişisel nitelikler, yönetici tutumu/davranışları, mesleki bilgiye erişim gibi değişkenlerin öne çıktı̆̆ 1 araştırmacılar tarafından vurgulanmıştır (Demirkıran ve Erdem, 2014: 206-307).

İngilizce yazında "intent to leave"," intent to quit", "intention to leave" şeklinde ifade edilen ve yaygın biçimde "işten ayrılma niyeti" olarak Türkçeleştirilen kavram, aslında sivil toplum kuruluşları veya sendikalar gibi gönüllü çalışma örgütlerinden ayrılmayı da kapsayabilen, başka bir deyişle yalnızca kişinin hizmetleri karşılığında ücret aldığı türden kâr amaçlı örgütleri ilgilendirmeyen bir meseledir (Price, 2001). Bu açıdan bakıldığında, ulusal yazında "ayrılma niyeti" kavramının, 'gelir kapısı olan örgütü terk ederek başka bir örgüte gitme arzusu' olarak ele alındığı ve bu yaklaşımın, çalışmaların her biri için geçerli olabilecek nadir ortak noktalardan biri olduğu söylenebilir. Gönüllü hizmetlere konu olan örgütlerden ayrılma niyetiyle ilgili çalışmalar, ulusal yazında yadsınmış görünmektedir. Bu anlamda, hem tekil çalışmalarda ulaşılan sonuçlar hem de mevcut çalışmanın bulguları, yalnızca kar amaçlı örgütleri ve bu örgütlerin genellikle tam zamanlı ve ücretli/maaşlı çalışanlarını ilgilendirecek biçimde yorumlanmalıdır. 
İşten ayrılma/işgören devri yazını gerçek yaşamda gözlemlenen olgulardan doğan bir araştırma alanı olduğundan, bu alanda yapılacak çalışmaların uygulamacılara özellikle faydalı olacağı varsayılabilir. Ancak, çok az sayıda yöneticinin akademik makaleleri okuduğu (Rynes vd., 2002), işletme teorisyenlerinin pratik faydadan ziyade kuram geliştirmeye odaklandığı (Pffefer, 2007) ve inovatif yönetim uygulamalarının çok azının kuramcı araştırmacılar tarafından geliştirildiği (Holtom vd., 2008) düşünülürse, her ne kadar akademik gelenekler gereği araştırmacılar çalışmalarının sonunda uygulamaya yönelik önerilerde bulunsalar da bunların geçerliliğini ve uygulanabilirliğini sınamak veya ölçmek mümkün görünmemektedir. Bu nedenle, bu meta-analizin uygulamacılara yönelik olarak söyleyebilecekleri, bireysel çalışmaların sınırlarından daha geniş değildir.

İsgören devrinin nedenlerini açıklamaya çalışan kuramsal modellerin incelendiği bir çalışmada (Demirkıran ve Erdem, 2014), bu modellerin önemli bir kısmının iş tatmini, örgütsel bağlılık ve örgütsel adalet değişkenlerinden beslendiğinin altı çizilmiştir. Farklı araştırmacıların da önerdiği üzere (Holtom vd., 2008) sıfır hipotezine karşın alternatif hipotezi yine ve yeniden sınamak yerine, bu türden kanıksanmış ilişkilerin gücüne yönelik önermeler geliştirmek (örneğin işten ayrılma niyeti-iş tatmini arasındaki korelasyon \%20'den fazla mıdır, az mıdır gibi) ve onları sınamak daha fazla marjinal fayda üretecektir. Elbette, daha az araştırılmış değişkenler ile işten ayrılma niyeti arasındaki ilişkiler bağlamında sıfır hipotezine karşın alternatif hipotez sınanabilir, ancak sözü edilen türden geleneksel ikililer arasındaki ilişkinin yönü ve anlamlılığı zaten defalarca araştırılmış/tespit edilmiştir. Bu açıdan, çalışmanın içleme ve dışlama kriterlerinin aktarıldığı kısımda sözü edilen ve meta-analiz için yeterli sayıya ulaşmamış araştırma alanlarında yapılacak çalışmalara ihtiyaç olduğu söylenebilir.

Son olarak, pozitivizmin, tipik olarak gerçeğin yalnızca ölçümleme ve metodolojik monizm ile mümkün olabileceği varsayımı, bu çalışmanın paradigma olarak taraflılığına işaret etmektedir (Eisner, 1992). Pozitivist ve nicel dayanaklı tekil çalışmaların en büyük zaaflarını teşkil eden küçük ve rassal olmayan örneklemler üzerinden analiz yapılması, yanlılıklar, ölçüm hataları, raporlama hataları, çekmecede unutulan yayınlar sorunsalı, anlamlılık durum ve düzeylerinin çalışmalar arasında farklılık göstermesi ve konuya ilişkin var olan her türden akademik çalışmanın kapsama dahil edilememesi (bildiri ve tezler gibi) ise çalışmanın diğer kısıtlarını oluşturmaktadır. Ancak, işten ayrılma niyeti konusunda ulusal yazında yayınlanan makaleleri çeşitli açılardan irdeleyen, eleştiren ve özetleyen türden kapsamlı, güncel ve sistematik bir değerlendirmeyi araştırmacıların ilgisine sunması açısından mevcut çalışmanın gelecek araştırmalara kılavuzluk etmesi ve yazına bu anlamda bir katkı sunması hedeflenmektedir. 


\section{KAYNAKÇA}

Meta-analize dahil edilen çalışmalar *asterisk ile işaretlenmiştir.

*Afacan-Fındıklı (2014). Algılanan lider desteği ve algılanan örgütsel destek ile ișten ayrılma niyeti ilişkisinde örgütsel özdeşlemenin aracılık rolü: İstanbul'da kamu çalışanları üzerine bir araştırma. İ.Ü. İşletme Fakültesi İşletme İktisadı Enstitüsü Yönetim Dergisi, 25(77), 136157.

*Akbolat, M., Yılmazer, A. \& Tutar, H. (2014). Konaklama işletmeleri çalışanlarının algıladıkları mobbingin iş tatmini ve işten ayrılma niyetine etkisi. Manas Sosyal Araştırmalar Dergisi, 3(3), 1-17.

Akgündüz, Y., \& Akdağ, G. (2014). İş görenlerin kişilik özelliklerinin temel benlik değerlendirmelerine ve işten ayrılma niyetlerine etkisi. Yönetim Bilimleri Dergisi, 12, 295-318.

*Akova, O., Emiroğlu, B.D., \& Tanrıverdi, H. (2015). The relationship between employees' job stress, job satisfaction and turnover intent: A study at five star hotels in Istanbul. Journal of Management, Marketing and Logistic, 2(4), 378-402.

*Akyüz, B. \& Eşitti, B. (2015). Hizmet İşletmelerinde örgütsel bağl1lığın iş performansı ve işten ayrılma niyeti üzerindeki etkisi: Çanakkale örnekleminde bir araştırma. Bartın Üniversitesi İ̈BF Dergisi, 6(11), 23-39.

Akyüz, M., \& Yılmaz, F. (2015). Konaklama işletmelerinde örgütsel özdeşleşme ve örgütsel iletişimin işgörenlerin işten ayrılma niyetine etkisi. Kastamonu Üniversitesi İktisadi ve İdari Bilimler Fakültesi Dergisi, 8(2), 138-143.

Alper-Ay, F., \& Keleş, K. (2017). Etkileşimci ve dönüşümcü liderlik tarzlarının işten ayrılma niyeti ve iş performansı üzerinde etkisi. Gümüşhane Üniversitesi Sağlık Bilimleri Dergisi, 6(4), 193-203.

*Alper-Ay, F. \& Türkdoğan, N. (2018). Duygusal emek, tükenmişlik, işten ayrilma niyeti ve iş performansı arasındaki ilişsiler. Örgütsel Davranış Araştırmaları Dergisi, 3(1), 87-103.

*Anafarta, N. (2015). Algılanan örgütsel destek ve işten ayrılma niyeti ilişkisi: İş tatmininin aracılık rolü. İ.Ü. İşletme Fakültesi İşletme İktisadı Enstitüsü Yönetim Dergisi, 26(79), 112-130.

Armstrong, C. E., \& Shimizu, K. (2007). A review of approaches to empirical research on the resource-based view of the firm. Journal of Management, 33(6), 959-986.

*Aslan, Z. (2014). İşgörenlerin tükenmişlik düzeylerinin işten ayrılma niyeti üzerine etkisi:İstanbul'daki seyahat acentalarında bir araştırma. Nevşehir Hacı Bektaş Veli Üniversitesi Sosyal Bilimler Enstitüsü Dergisi, 3, 19-40.

*Aslan, Z. \& Etyemez, S. (2015). İşgörenlerin tükenmişlik düzeylerinin işten ayrılma niyeti üzerine etkisi: Hatay'daki otel işletmelerinde bir araştırma. İşletme Araştırmaları Dergisi, 7(3), $482-507$.

*Aslan, Ş. \& Uyar, S. (2018). Psikolojik sözleşme ihlali ile hissettirdiklerinin örgütsel özdeşleşme, iş tatmini ve işten ayrılma niyeti üzerine etkileri. Dokuz Eylül Üniversitesi İktisadi ve İdari Bilimler Fakültesi Dergisi, 33(1), 1-38.

Atinc, G., Darrat, M., Fuller, B., \& Parker, B. W. (2010). Perceptions of organizational politics: A meta-analysis of theoretical antecedents. Journal of Managerial Issues, 22(4), 494-513.

*Bakan, İ., Erşahan, B., Büyükbeşe, T., Okumuş, M.T., \& Akmeşe, A. (2017). Öğretmenlerin işe yönelik davranışlarında (örgütsel stres, iş yükü, işten ayrılma niyeti ve iş tükenmişliği) örgütsel desteğin rolü: Bir alan araştırması. International Journal of Disciplines Economics \& Administrative Sciences Studies, 3(4), 444-464.

Başar U., \& Varoğlu, A. (2016). Örgütsel politika algısının ihmalkarlık üzerindeki etkisinde işten ayrılma niyetinin aracı rolü. Yönetim ve Ekonomi Dergisi, 23(3), 753-767.

Begg, C.B., \& M. Mazumdar, (1994). Operating characteristics of a rank correlation test for publication bias. Biometrics, 50, 1088-1101.

*Beğenirbaş, M., \& Çalışkan, A. (2014). Duygusal emeğin iş performansı ve işten ayrılma niyetine etkisinde kişilerarası çarpıklığın aracılık rolü. Business and Research Journal, 5(2), 109127. 
Berry. M.L., \& Morris, M. L. (2008). The impact of employee engagement factors and job satisfaction on turnover intent. Paper presented at the Academy of Human Resource Development International Research Conference in the Americas.

Bluedorn, A.C. (1982). A Unified model of turnover from organizations. Human Relations, 35, 135 153.

Bodla, M.A., \& Hameed, A. (2008). Factors affecting employee turnover intentions: Empirical evidence from textile sector of Pakistan. The International Journal of Knowledge, Culture and Change Management, 9(8), 53-64.

Bolat, O.I., Bolat, T., Seymen, O., \& Katı, Y. (2017). Otellerde nepotizm (akraba kayırmacılığı) ve işten ayrılma niyeti ilişkisi: kariyer düzleşmesinin aracılık etkisi. Manas Sosyal Araştırmalar Dergisi, 6(3), 157-180.

*Bozacı, İ., Çiftçi, G.E., \& Gürer, A. (2018). Algılanan yönetici kibrinin, satış elemanlarının tükenmişlik ve işten ayrılma niyeti üzerindeki etkisine yönelik bir alan araştırması. Hitit Üniversitesi Sosyal Bilimler Enstitüsü Dergisi, 11(1), 205-226.

*Bulut, M.B., \& Hovardaoğlu, İ. S. (2018). Örgütsel bağl1lık, örgütsel sinizm ve işten ayrılma niyetinin yatırım modeli çerçevesinde incelenmesi. Uluslararası Sosyal Araştırmalar Dergisi, 11(56), 270-289.

Bulut, M.B. (2017). Erkek çalışanların örgütsel bağlılık, örgütsel sinizm ve işten ayrılma niyetlerinin yatırım modeli çerçevesinde incelenmesi. (Yayımlanmamış Doktora Tezi). Ankara Üniversitesi, Ankara.

Burrell, G., \& Morgan, G. (1979). Sociological Paradigms and Organizational Analysis. London: Heinemann.

Büyükbeşe, T., \& Gökaslan, M. (2018). İşe gömülmüşlük, işe adanmışlık ve işten ayrılma niyeti ilişkisi: Bir alan çalışması. Mukaddime, 9 (2), 135-154.

Cammann, C., Fichman, M., Jenkins, D., \& Klesh, J. (1979). The Michigan organizational assessment questionnaire. Unpublished Manuscript, University of Michigan, Ann Arbor.

Carmeli, A., \& Weisburg, J. (2006). Exploring turnover intentions among three professional groups of employees. Human Resource Development International, 9(2), 191-206.

Carsten, J.M., \& Spector, P.E. (1987). Unemployment, job satisfaction and employee turnover: A meta-analytic test of the Muchinsky model. Journal of Applied Psychology, 72, 374-381.

Cerit, Y., \& Özdemir, T. (2016). Sınıf öğretmenlerinin iş yükü algıları ile işten ayrılma niyetleri arasındaki ilişki. International Journal of Human Sciences, 12(2), 626-637.

Chiu, K. C., Chien, S. C., Lin, P. C., \& Hsiao,Y. C. (2005).Understanding hospital employee job stress and turn over intentions in a practical setting, the moderating role of locus of control. Internet Research, 24(10), 837-855.

Cohen, J. (1992). Quantitative methods in psychology: A power primer. Psychological Bulletin, 112(1), 155-159.

Cohen, L., Manion, L., \& Morrison, K. (2007). Research methods in education (6th ed.). New York, NY, US: Routledge/Taylor \& Francis Group.

Cotton, J. L., \& Tuttle, J. M. (1986). Employee turnover: A meta-analysis and review with implications for research, The Academy of Management Review, 11(1), 55-70.

*Çankır, B., \& Şahin, S. (2018). Sürdürülebilir kalite algısının işten ayrılma niyeti üzerindeki etkisinde iş tatmininin aracı rolü. Uluslararası İktisadi ve İdari İncelemeler Dergisi, 17. UíK Özel Sayısı, 135-146.

Çelik, M., \& Çıra, A. (2013). Örgütsel vatandaşlık davranışının iş performansı ve işten ayrılma niyeti üzerine etkisinde aşırı iş yükünün aracılık rolü. Ege Akademik Bakış, 13(1), 11-20.

*Çelik, M. \& Yıldız, B. (2016). Duygusal emek düzeyinin işten ayrılma niyeti üzerindeki etkisinde stresin aracı rolü. Uluslararası Sosyal Araştırmalar Dergisi, 9(45), 734-745.

*Çelik, M., \& Yıldız, B. (2018). Hemşirelerde mesleki bağlılık, özdeşleşme ve işten ayrılma niyeti ilişkisi: Kamu sektörü ve özel sektör karşılaştırması. Kastamonu Üniversitesi İktisadi ve İdari Bilimler Fakültesi Dergisi, 20(2), 47-75.

*Çetin, A., Güleç, R., \& Kayasandık, A.E. (2015). Etik iklim algısının çalışanların işten ayrılma niyetine etkisi: tükenmişliğin aracı değişken rolü. Electronic Journal of Vocational Colleges, 5(2), 18-31. 
*Çınar, O., Karcıoğlu, F., \& Akdaş, K. (2016). İş yaşamında iş tatmini, örgütsel özdeşleme ve işten ayrılma niyeti ilişkisi: Erzurum'da bir kamu kurumu örneği. Siyaset, Ekonomi ve Yönetim Araştırmaları Dergisi, 4(3), 121-136.

*Demir, M. (2012). Örgütsel destek, örgütsel bağlılık ve işten ayrılma eğilimi ilişkisi: havalimanı yer hizmetleri işletmelerine yönelik bir araştırma. "İşGüç" Endüstri İlişkileri ve İnsan Kaynakları Dergisi, 14(1), 47-64.

*Demir, S. (2018). Etik iklim ve okuldan ayrılma niyeti arasındaki ilişki: Örgütsel bağlılığın aracılık rolü. Hacettepe Üniversitesi Eğitim Fakültesi Dergisi. Doi: 10.16986/HUJE.2018040551.

*Demircan-Çakar, N., \& Ceylan, A. (2005). İş motivasyonunun çalışan bağlılığı ve işten ayrılma eğilimi üzerindeki etkileri. Doğuş Üniversitesi Dergisi, 6(1), 52-66.

Demirkıran, M., \& Erdem, R. (2014). Personel devrinin nedenlerine ilişkin geliştirilen modellerin incelenmesi. Süleyman Demirel Üniversitesi İktisadi ve İdari Bilimler Fakültesi Dergisi, 19(3), 289-311.

Eisner, E. W. (1992). Are all causal claims positivistic? A reply to Francis Schrag. Educational Researcher, 21(5), 8-9.

Ekin, N. (1960). Memleketimizde işçi devri mevzuunda yapılan araştırmalar ve ortaya koydukları neticeler. Sosyal Siyaset Konferansları Dergisi, 9-10-11, 123-192.

*Ekmekçioğlu, E.B., \& Sökmen, A. (2016). Algılanan örgütsel desteğin işten ayrılma niyetine etkisinde örgütsel bağlılığın aracı rolü: sınır birimi çalışanları üzerine bir araştırma. International Review of Economics and Management, 4(2), 32-45.

*Erdilek-Karabay, M. (2015). Sağlık personelinin iş stresi, iş- aile çatışması ve iş-aile-hayat tatminlerine yönelik algılarının işten ayrılma niyeti üzerindeki etkilerinin belirlenmesi üzerine bir araştırma. Yönetim Bilimleri Dergisi, 13(26), 113-134.

*Erkuş A., \& Afacan-Fındıklı, M. (2013). Psikolojik sermayenin iş tatmini, iş performansı ve işten ayrılma niyeti üzerindeki etkisine yönelik bir araştırma. Journal of the School of Business Administration, 42(2), 302-318.

Eroğlu, A., Topçu, M.K., \& Basım, N. (2018). Bireysel yenilikçi davranışların çalışma arkadaşları ile çatışma ve işten ayrılma niyeti üzerine etkileri: Kamu sektöründe bir araştırma. Business and Economics Research Journal, 9(1), 123-136.

*Eşitti, B. (2018). Konaklama işletmelerinde iş değerlerinin işten ayrılma niyetine etkileri: iş-aile-iş çatışmasının aracı rolü. Verimlilik Dergisi, 3, 235-257.

Field, A. P., \& Gillett, R. (2010). How to do a meta-analysis. British Journal of Mathematical \& Statistical Psychology, 63(3), 665-694.

*Giray, M.D., \& Şahin, D.N. (2014). Liderlik stillerinin duygusal bağl1lık ve işten ayrılma niyetiyle ilişkilerinde örgütsel destek algısının aracılık rolü. Türk Psikoloji Dergisi, Haziran, 29(73), 1-14.

*Gökaslan, M.O. (2018). Öğretmenlerde örgütsel bağl1lık, işe gömülmüşlük, işe adanmışlık ve işten ayrılma niyeti ilişkisi: Bir alan çalışması. Türk Sosyal Bilimler Araştırmaları Dergisi, 3(2), 25-46.

Güçer, E., Pelit, Demirdağ, E.Ş., \& Keleş, Y. (2017). Kaytarmanın işten ayrılma niyeti üzerindeki işletmelerinde bir araştırma. İşletme Araştırmaları Dergisi, 9(2), 14-36.

*Gül, H., Oktay, E., \& Gökçe, H., (2008). İş tatmini, stres, örgütsel bağlılık, işten ayrılma niyeti ve performans arasındaki ilişkiler: Sağlık sektöründe bir uygulama. Akademik Bakış, Uluslararası Hakemli Sosyal Bilimler E-Dergisi, 20, 1-11.

*Gündüz-Çekmecelioğlu, H. (2005). Örgüt ikliminin iş tatmini ve işten ayrılma niyeti üzerindeki etkisi: Bir araştırma. C.Ü. İktisadi ve İdari Bilimler Dergisi, 6(2), 23-39.

*Gündüz-Çekmecelioğlu, H. (2014). Göreve ve insana yönelik liderlik tarzlarının örgütsel bağlılık, iş performansı ve işten ayrılma niyeti üzerindeki etkileri. Kocaeli Üniversitesi Sosyal Bilimler Dergisi, 28, 21-34.

*Günlük, M., Özer, G., \& Özcan, M. (2013). İş memnuniyetinin muhasebecilerin örgütsel bağlll1k ve işten ayrılma eğilimleri üzerindeki etkisi. Uluslararası Yönetim İktisat ve İşletme Dergisi, 9(20), 55-74. 
*Gürbüz, S., \& Bekmezci, M. (2012). İnsan kaynakları yönetimi uygulamalarının bilgi işçilerinin işten ayrılma niyetine etkisinde duygusal bağlılığın aracılık ve düzenleyicilik rolü. İstanbul Üniversitesi İşletme Fakültesi Dergisi, 41(2), 189-213.

Güzel, B., \& Ayazlar, G. (2014). Örgütsel adaletin örgütsel sinizm ve işten ayrılma niyetine etkisi: otel işletmeleri araştırması. KMÜ Sosyal ve Ekonomik Araştırmalar Dergisi, 16(26), 133142.

Halawi, A.H. (2014). Stimuli and effect of intention to leave the organization. European Scientific Journal, 1, 184-197.

Hanisch, K. A., \& Hulin, C. L. (1990). Job attitudes and organizational withdrawal: An examination of retirement and other voluntary behaviors. Journal of Vocational Behavior, 37, 6078.

Hanisch, K. A., \& Hulin, C. L. (1991). General attitudes and organizational withdrawal: An evaluation of a causal model. Journal of Vocational Behavior, 39, 110-128.

Herzberg, F.I. (1966). Work and the nature of man. Oxford, England: World.

Holtom, B.C., Mitchell, T.R., Lee, T.W., \& Eberly, M.B. (2008). 5 turnover and retention research: A glance at the past, a closer review of the present, and a venture into the future. The Academy of Management Annals, 2(1), 231-274.

Hom, P.W., Griffeth, R.W., \& Sellaro, C. L. (1984). The validity of mobley's 1977 model of employee turnover. Organizational Behavior and Human Performance, 34, 141-174.

Homans, G. (1958). Social behavior as exchange. American Journal of Sociology, 63(6), 597-606.

Hulin, C.L., Roznowski, M., \& Hachiya, D. (1985). Alternative opportunities and withdrawal decisions: Empirical and theoretical discrepancies and an integration. Psychology Bulletin, 97, 223-250.

*Karaca, M., Biçkes, D.M., Çakı, C., \& Karaduman, G. (2017). Medya yöneticilerinin iş tatmin düzeylerinin işten ayrılma niyetleri üzerindeki etkisi: Malatya örneği. Gümüşhane Üniversitesi İletişim Fakültesi Dergisi, 5(2), 969-990.

*Karakaş, A. (2017). Duygusal emek, tükenmişlik ve işten ayrılma niyeti arasındaki ilişki: Otel işletmesi çalışanları üzerine bir araştırma. İşletme Araştırmaları Dergisi, 9(1), 80-112.

Karakuş, M., Toprak, M., \& Gürpınar, M. (2014). Structural equation modelling on the relationships between teacher's trust in manager, commitment to manager, satisfaction with manager and intent to leave, croatian. Journal of Education, 16(1), 165-189.

*Kartopu, M., \& Gürbüz , S. (2016). Askerî pilotların örgütsel bağlılıklarının, işten ayrılma niyetlerine etkisi: Alternatif iş imkânlarının düzenleyicilik rolü. Savunma Bilimleri Dergisi, 15(1), 79-112.

*Kitapçı, H., Kaynak, R., \& Ökten, S.S. (2013). Güçlendirmenin iş tatmini ve işten ayrılma niyetine etkisi: Kamu ve özel sektörde mukayeseli bir araştırma. International Review of Economics and Management, 1(1), 49- 73.

*Koçak, D., \& Yücel, İ. (2018). Algılanan örgütsel destek ile işten ayrılma niyeti arasındaki ilişkide duygusal bağlılığın aracı etkisinin incelenmesi. Atatürk Üniversitesi İktisadi ve İdari Bilimler Dergisi, 32(3), 683-704.

March, J.G., \& Simon, H.A. (1958). Organizations. New York: John Wiley.

Mimaroğlu-Özgen, H., \& Özgen, H. (2010). Psikolojik sözleşme ve boyutlarının iş tatmini, örgütsel bağlılık ve işten ayrılma niyetine etkileri: Tibbi satış temsilcileri üzerinde bir araştırma. Çukurova Üniversitesi Sosyal Bilimler Enstitüsü Dergisi, 19(1),1-19.

Mobley, W.H. (1977). Intermediate linkages in the relationship between job satisfaction and employee turnover. Journal of Applied Psychology, 62(2), 237- 240.

Mowday, R. T, Koberg, C. S., \& Mcarthur, A.W. (1984). The psychology of the withdrawal proces: a cross-validational test of mobley's intermediate linkages model of turnover in two samples. Academy of Management Journal, 27(1), 79-94.

*Mumcu, A., \& Alıcı, İ. (2016). Örgütsel bağlılığın alt boyutları ile işten ayrılma niyeti arasındaki ilişki: Sosyal yardımlaşma ve dayanışma vakfı personeli üzerine bir araştırma. Örgütsel Davranış Araştırmaları Dergisi, 1(1), 35-52.

Ngo-Henha, P.E. (2017). A review of existing turnover intention theories. International Journal of Economics and Management Engineering, 11(11), 2760-2767. 
Ongori, H. (2007). A review of the literature on employee turnover. African Journal of Business Management, 1(3), 49-54.

*Özer, G., \& Günlük, M. (2010). Örgütsel adaletin muhasebecilerin iş memnuniyeti ve işten ayrılma eğilimine etkisi. Gaziantep Üniversitesi Sosyal Bilimler Dergisi, 9(2), 459-485.

*Öztürk, M., \& Eryeşil, K. (2016). Lideüye etkileşimi ve örgütsel destek algılarının çalışanların işten ayrılma niyeti üzerindeki etkisi. Sosyal Bilimler Meslek Yüksekokulu Dergisi, 19(2), 123-141.

Perez, M. (2008). Turnover intent. Diploma Thesis. University of Zurich. https://docplayer.net/20983210-Turnover-intent-diploma-thesis.html

Pfeffer, J. (2007). A modest proposal: How we might change the process and product of managerial research. Academy of Management Journal, 50, 1334-1345.

Price, J.L. (2001). Reflections on the determinants of voluntary turnover. International Journal of Manpower, 22(7), 600-624.

*Poyraz, K., \& Kama, B. (2008). Algılanan iş güvencesinin, iş tatmini, örgütsel bağl1lık ve işten ayrılma niyeti üzerindeki etkilerinin incelenmesi. Süleyman Demirel Üniversitesi İktisadi ve İdari Bilimler Fakültesi Dergisi, 13(2), 143-164.

Rahman, W., \& Nas, Z. (2013). Employee development and turnover intention: Theory validation. European Journal of Training and Development, 37(6), 564-579.

Rosenthal, R. (1979). The 'file drawer' problem and tolerance for null results. Psychological Bulletin, 86, 638-641.

Rosin, H., \& Korabik, K. (1995). Organizational experiences and propensity to leave: A multivariate investigation of men and women managers. Journal of Vocational Behavior, 46(1), 1-16.

Rusbult, C., Farrell, D., Rogers, G. ve Mainous A. (1988). Impact of exchange variables on exit, voice, loyalty, and neglect: An integrative model of responses to declining job satisfaction. Academy of Management Journal, 31(3), 599-627.

Rynes, S.L., Colbert, A.E., \& Brown, K.G. (2002). HR professionals' beliefs about effective human resource practices: Correspondence between research and practice. Human Resource Management, 41, 149-174.

*Sağlam-Arı, G., Bal, H., \& Çına-Bal, E. (2010). İşe bağlılığın tükenmişlik ve işten ayrılma niyeti ilişkisindeki aracılık etkisi: Yatırım uzmanları üzerinde bir araştırma. Süleyman Demirel Üniversitesi İktisadi ve İdari Bilimler Fakültesi Dergisi, 15(3), 143-166.

Seashore, S.E., Lawler, E.E., Mirvis, P., \& Cammann, C., (1982). Observing and measuring organizational change: A guide to field practice, New York, Wiley.

Seçilmiş, C., \& K1lı̧, İ. (2017). Örgütsel güven, iş-aile çatışması ve işten ayrılma niyeti ilişkisinin belirlenmesi: Seyahat acentelerinde bir uygulama. Turizm Akademik Dergisi, 4(1), 65-79.

Serçeoğlu, N., Iş̧ı, Z., \& Çetinkaya, M. Y. (2016), İşyeri zorbalığının işten ayrılma niyeti üzerine ekisi: Konaklama işletmelerinde çalışan personel üzerine bir araştırma, Uluslararası Sosyal Araştırmalar Dergisi, 9(45), 1099-1109.

*Sevinç-Altaş, S., \& Kuzu, A. (2016). Sağlık çalışanlarında iş tatmini ve duygusal bağl1lığın bireysel iş performansı ve işten ayrılma eğilimi üzerindeki etkileri. International Journal of Academic Value Studies, 2(5), 23-32.

*Sökmen A., \& Aydıntan, B. (2016). Kariyer geleceği algısının iş tatmini ve işten ayrılma niyetine etkisi: Bir kamu kurumunda araştırma. Journal of Business Research Turk, 8(3), 251-263.

*Sökmen, A. \& Ceyhun-Sezgin, A. (2017). İş tatmini ve işten ayrılma niyetinin değerlendirilmesi: Otel işletmeleri sınır birim çalışanları üzerine bir araştırma. Journal of Tourism and Gastronomy Studies, 5(2), 237-250.

*Sökmen, A., \& Şimşek, T. (2016). Örgütsel bağlllık, örgütle özdeşleşme, stres ve işten ayrılma niyeti ilişkisi: Bir kamu kurumunda araştırma. Gazi Üniversitesi İktisadi ve İdari Bilimler Fakültesi Dergisi, 18(3), 606-620

Steel, R. P., \& Ovalle, N. K. (1984). A review and meta-analysis of research on the relationship between behavioral intentions and employee turnover. Journal of Applied Psychology, 69(4), 673-686. 
Tak, B., \& Çiftçioğlu, B.A. (2008). Mesleki bağlılık ile çalışanların örgütte kalma niyeti arasındaki ilişkiyi incelemeye yönelik görgül bir çalışma. Ankara Üniversitesi Siyasal Bilgiler Fakültesi Dergisi, 63(4), 155-178.

Tanrıverdi, H., Akova, O., \& Çifçi, İ. (2016). Açılış otellerinde dönüşümcü, etkileyici, tam serbestlik tanıyan liderlik tarzlarının ve çatışma yönetim stillerinin işten ayrılma niyeti üzerine etkisi. KMÜ Sosyal ve Ekonomik Araştırmalar Dergisi, 18(30), 114-123.

Tanrıverdi, H., Koçaslan, G., \& Osmanoğlu-Taştan, N. (2018). Psikolojik şiddet algısı, tükenmişlik sendromu ve işten ayrılma niyeti arasındaki ilişki: Banka çalışanları üzerinde bir araştırma. Yönetim ve Ekonomi Dergisi, 25(1), 113-131.

*Taslak, S. (2015). Banka çalışanlarının işten ayrılma niyetleri üzerinde etkili olan faktörlere yönelik bir araştırma: Muğla ili örneği. Mehmet Akif Ersoy Üniversitesi Sosyal Bilimler Enstitüsü Dergisi, 7(12), 145-160.

Taşlıyan, M., \& Hırlak B. (2016). Otantik liderlik, psikolojik sermaye, işten ayrılma niyeti ve çalışan performansı arasındaki ilişki: Hemşireler üzerinde bir araştırma. Akademik Bakış Uluslararas1 Hakemli Sosyal Bilimler Dergisi, 56, 92-115.

*Tekingündüz, S., \& Kurtuldu, A. (2015). İşten ayrılma niyeti, iş tatmini, örgütsel bağl1lık, liderlik ve iş stresi arasındaki ilişkilerin analizi: Bir hastane örneği. International Journal of Human Sciences, 12(1), 1501-1517.

*Tekingündüz, S., Top, M., \& Seçkin, M. (2015). İş tatmini, performans, iş stresi ve işten ayrılma niyeti arasındaki ilişkilerin incelenmesi: Hastane örneği. Verimlilik Dergisi, 4, 39-64.

*Tolay-Sabuncuoğlu, E. (2007). Eğitim, örgütsel bağlılık ve işten ayrılma niyeti arasındaki ilişkilerin incelenmesi. Ege Akademik Bakış, 7(2), 631-636.

*Tolukan, E., Şahin, M.Y., \& Koç, M. (2016). Cimnastik antrenörlerinin örgütsel özdeşleşme düzeyleri ve işten ayrılma niyeti ilişkisi. Turkish Studies, 11(8), 377-398.

*Topçu, M.K., \& Basım, H.N. (2015). Kobi'lerde çalışanların kişilik özelliklerinin örgütsel özdeşleşme ve işten ayrılma niyeti üzerine etkisinde psikolojik sözleşme algısının rolü. Turkish Studies, 10(10), 861-886.

*Tuna, M., \& Yeşiltaş, M. (2014). Etik iklim, işe yabancılaşma ve örgütsel özdeşleşmenin işten ayrılma niyeti üzerindeki etkisi: Otel işletmelerinde bir araştırma. Anatolia: Turizm Araştırmaları Dergisi, 25(1), 105-117.

*Turunç, Ö., \& Avcı, U. (2015). Algılanan örgütsel destek ve lider-üye etkileşiminin işten ayrılma niyeti üzerindeki etkisi: İş stresinin aracılık rolü. Seyahat ve Otel İşletmeciliği Dergisi, 12(1), 43-63.

*Turunç, Ö., \& Çelik, M. (2010). Algılanan örgütsel desteğin çalışanların iş-aile, aile-iş çatışması, örgütsel özdeşleşme ve işten ayrılma niyetine etkisi: Savunma sektöründe bir araştırma. Atatürk Üniversitesi Sosyal Bilimler Enstitüsü Dergisi, 14(1), 209-232.

Uslu, S., \& Aktaş, H. (2017). İşten ayrılma niyeti ile örgütsel sessizlik etkileşiminde iş güvencesi memnuniyeti ve iş güvencesi endeksinin aracı rolü: Özel bir hastane çalışanları üzerinde bir araştırma. Eskişehir Osmangazi Üniversitesi İktisadi ve İdari Bilimler Dergisi, 12, 141 160.

*Uştu, H., \& Tümkaya, S. (2017). Sınıf öğretmenlerinin mesleki bağlllık, işten ayrılma niyeti ve bazı sosyo-demografik özelliklerinin örgütsel bağlılığı yordama düzeylerinin incelenmesi. İlköğretim Online, 16(3), 1262-1274.

Uysal-Irak, D. (2014). Birey-çevre uyumu: çalışanların örgüt uyumlarının yaşama ilişkin doyum ve işten ayrılma niyetiyle ilişkisi. Türk Psikoloji Dergisi, 29(74), 34-45.

*Uzun, T. (2018). Öğretmenlerin algıladığı örgütsel destek ile örgütsel özdeşleşme ve işten ayrılma niyeti arasındaki ilişki: Örgütsel güvenin aracı rolü. Karadeniz Sosyal Bilimler Dergisi, 10(18), 133-155.

Walsh, J. P., Ashford, S. J., \& Hill, T. E. (1985). Feedback obstruction: The influence of the information environment on employee turnover intentions. Human Relations, 38, 23-46.

*Wasti, S. A. (2003). The Influence of cultural values on antecedents of organizational commitment: An individual level analysis. Applied Psychology: An International Review, 52 (4), 533-554. 
Wayne N.J., Shore L.M., \& Liden R.C. (1997). Perceived organizational support and leader-member exchange, a social exchange perspective. Academy of Management Journal, 40, 82-111.

Winterton, J. (2004). A conceptual model of labour turnover and retention. Human Resource Development International, 7(3), 371-390.

*Yavuz, M., \& Akca, M. (2018). Çatışma, stres, tükenmişlik ve işten ayrılma niyeti: Medeni durum ve cinsiyete göre farklılıkların incelenmesi. İşletme Araştırmaları Dergisi, 10(2), 827-846.

*Yazıcıoğlu, İ. (2009). Konaklama işletmelerinde işgörenlerin örgütsel güven duyguları ile iş tatmini ve işten ayrılma niyetleri üzerine bir alan araştırması. Elektronik Sosyal Bilimler Dergisi, 8(30), 235-249.

Yener, S. (2018). Psikolojik rahatlık algısının otantik liderliğin sinizmin üzerindeki etkisinde aracı rolü. Eskişehir Osmangazi Üniversitesi İktisadi ve İdari Bilimler Dergisi, 13(1), 1-14.

*Yeşil, S., \& Mavi, Y. (2018). Duygusal emeğin etkilediği faktörler üzerine bir alan araştırmas1. Aksaray Üniversitesi İktisadi ve İdari Bilimler Fakültesi Dergisi, 1, 29-44.

*Yıldız, S.M. (2014). İçsel pazarlamanın iş tatmini ve işten ayrılma niyeti üzerindeki rolü: Spor ve fiziksel etkinlik işletmeleri üzerine ampirik bir inceleme. Ege Akademik Bakış, 14(1), 137-146.

*Yıldız, S., Savcı, G., \& Kapu, H. (2014). Motive edici faktörlerin çalışanların iş performansına ve işten ayrılma niyetine etkisi. Yönetim ve Ekonomi, 21(1), 233-249.

Yıldız, B., \& Ayaz-Arda, Ö. (2018). İyi bir asker mi? İyi bir illüzyonist mi? Kariyerizm ile zorunlu vatandaşlık davranışları arasındaki ilişkide işten ayrılma niyetinin rolü. Business and Economics Research Journal, 9(1), 151-167.

*Yıldız, S., Yalavaç, S., \& Meydan, C.H. (2013). Tükenmişliğin işten ayrılma niyetine etkisinde örgüte bağlılığın aracı rolü: Türkiye'deki gümrük ve ticaret bakanlığı personeli üzerinde bir araştırma. Akdeniz İ̈BF Dergisi, 26, 164-189.

*Yücel, İ., \& Demirel, Y. (2013). Mevcut iş alternatiflerinin iş tatmini ve işten ayrılma ilişkisi üzerine etkisi: "Başka bir yol daha olmalı!” Atatürk Üniversitesi İktisadi ve İdari Bilimler Dergisi, 27(2), 159-177.

*Yücel, İ., \& Koçak, D. (2018). İş tatmini ve işten ayrılma niyeti arasındaki ilişkide tükenmişliğin aracılık etkisi: Sağlık sektöründe bir çalışma. MANAS Sosyal Araştırmalar Dergisi, 7(2), 297-321.

*Yüksel, H., \& Yüksel, M. (2014). İş doyumu ile işten ayrılma düzeyi arasındaki ilişki: İlköğretim öğretmenleri üzerinde bir uygulama. Uluslararası Sosyal Araştırmalar Dergisi, 7(32), 559572.

*Yürür, Ş., \& Ünlü, O. (2011). Duygusal emek, duygusal tükenme ve işten ayrılma niyeti ilişkisi, "İşGüç" Endüstri İlişkileri ve İnsan Kaynakları Dergisi, 13(1), 81-104.

Zhang, M., Fried, D. D., \& Griffeth, R. W. (2012). A review of job embeddedness: Conceptual, measurement issues, and directions for future research. Human Resource Management Review, 22, 220-231.

*Zincirkıran, M., Mat-Çelik, G., Ceylan, A.K., \& Emhan, A. (2015). İşgörenlerin örgütsel bağl1lık, işten ayrılma niyeti, iş stresi ve iş tatmininin örgütsel performans üzerindeki etkisi: Enerji sektöründe bir araştırma. Finans, Politik ve Ekonomik Yorumlar, 52(600), 59-71.

Zula, K. J., \& Chermack, T. J. (2007). Integrative literature review: Human capital planning: a review of literature and implications for human resource development. Human Resource Development Review, 6(3), 245-262.

\section{SUMMARY}

The literature on employee turnover - a highly undesired and detrimental employee behavior- in the particular context of employees partaking in paid work, has historically been focused on symptoms of the act of leaving rather than on real causes and cures. As such, the scholarly endeavors have concentrated on one of the closest correlates of this behavior and its most imminent precursor, namely the intention to leave. The intention to leave, a comparatively less obvious 
concept compared to turnover, is considered to be an indicator of an employee's (usually negative) attitude toward the organization and the willingness to terminate the employment contract. This intention also heralds an upcoming planned behavior within a specific time period. The intention to leave has almost always been associated with negative feelings, attitudes and consequences for organizational well-being. The current study seeks to find out the plethora of antecedents most frequently associated with intention to leave in Turkish organization literature and to investigate the direction and power of those associations. Specifically, the study aims to make a systematic review of studies on the antecedents of "intention to leave" in the context of articles featuring samples from Turkey and published in national/international peer-reviewed journals, and hence to generate a comprehensive model of intention to leave antecedents.

According to fifteen different meta-analyses based on correlation coefficients and sample sizes, the most frequently investigated antecedent of intention to leave is job satisfaction, followed by affective commitment, organizational commitment, continuance commitment, perceived organizational support, normative commitment, organizational identification, job stress, emotional exhaustion, surface acting, depersonalization, personal accomplishment, deep acting, burnout and job performance respectively. Organizational commitment meta-analyses reveal that the highest correlation occurs with affective commitment and the smallest correlation occurs with continuance commitment. The negative correlation between identification and intention to leave is quite small. Job stress and intention to leave are positively correlated at a medium-level. However, there is a very small and negligible correlation between intention to leave and job performance, contrary to prevailing opinion. None of the meta-analyses display "highly powerful" correlations between variables of interest except for emotional exhaustion, perceived organizational support and depersonalization. The highest negative correlation is found between intention to leave and perceived organizational support, and the largest positive correlation is between that of intention to leave and emotional exhaustion. There are different scales used for operationalizing intention to leave with Cammann and colleagues' (1979) three-item scale being the most popular measurement instrument. None of the intention to leave scales includes more than one dimension or subscale. As for study populations, the samples cover a wide range of different sectors including but not limited to health, education, tourism, bank, defense industry and local government offices and all participants are, one way or another, "paid" workers. All studies are based on cross-sectional data collected at a specific time point with a self-report design.

Overall, we expect this paper to make a modest contribution to the extant literature on the intention to leave by providing a comprehensive and up-to-date review of the empirical studies in the national context. 